\title{
ABOVE THE WELL
}

AN ANTIRACIST LITERACY ARGUMENT

\section{FROM A BOY OF COLOR}

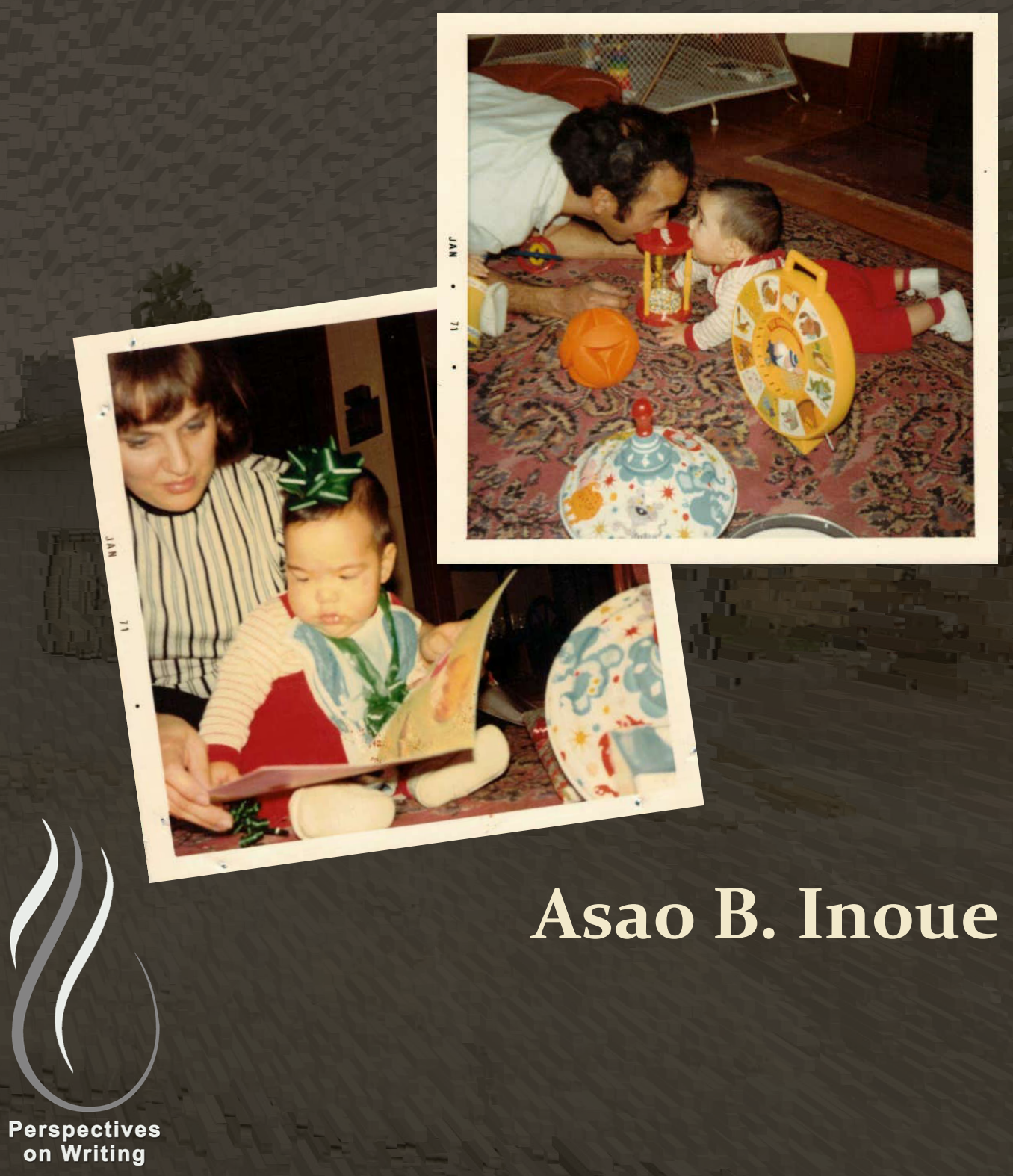





\section{ABOVE THE WELL: \\ AN ANTIRACIST LITERACY ARGUMENT FROM A BOY OF \\ COLOR}




\section{PERSPECTIVES ON WRITING}

Series Editors, Rich Rice, Heather MacNeill Falconer, and J. Michael Rifenburg Consulting Editor, Susan H. McLeod | Associate Series Editor, Jonathan P. Hunt

The Perspectives on Writing series addresses writing studies in a broad sense. Consistent with the wide ranging approaches characteristic of teaching and scholarship in writing across the curriculum, the series presents works that take divergent perspectives on working as a writer, teaching writing, administering writing programs, and studying writing in its various forms.

The WAC Clearinghouse, Colorado State University Open Press, and University Press of Colorado are collaborating so that these books will be widely available through free digital distribution and low-cost print editions. The publishers and the Series editors are committed to the principle that knowledge should freely circulate. We see the opportunities that new technologies have for further democratizing knowledge. And we see that to share the power of writing is to share the means for all to articulate their needs, interest, and learning into the great experiment of literacy.

\section{Recent Books in the Series}

Alexandria Lockett, Iris D. Ruiz, James Chase Sanchez, and Christopher Carter. Race, Rhetoric, and Research Methods (2021)

Kristopher M. Lotier, Postprocess Postmortem (2021).

Ryan J. Dippre and Talinn Phillips (Eds.), Approaches to Lifespan Writing Research: Generating an Actionable Coherence (2020)

Lesley Erin Bartlett, Sandra L. Tarabochia, Andrea R. Olinger, and Margaret J. Marshall (Eds.), Diverse Approaches to Teaching, Learning, and Writing Across the Curriculum: IWAC at 25 (2020)

Hannah J. Rule, Situating Writing Processes (2019)

Asao B. Inoue, Labor-Based Grading Contracts: Building Equity and Inclusion in the Compassionate Writing Classroom (2019)

Mark Sutton and Sally Chandler (Eds.), The Writing Studio Sampler: Stories About Change (2018)

Kristine L. Blair and Lee Nickoson (Eds.), Composing Feminist Interventions: Activism, Engagement, Praxis (2018)

Mya Poe, Asao B. Inoue, and Norbert Elliot (Eds.), Writing Assessment, Social Justice, and the Advancement of Opportunity (2018)

Patricia Portanova, J. Michael Rifenburg, and Duane Roen (Eds.), Contemporary Perspectives on Cognition and Writing (2017) 


\title{
ABOVE THE WELL: AN ANTIRACIST LITERACY ARGUMENT FROM A BOY OF COLOR
}

\author{
By Asao B. Inoue
}

The WAC Clearinghouse wac.colostate.edu Fort Collins, Colorado

Utah State University Press upcolorado.com/utah-state-university-press Logan, Utah 
The WAC Clearinghouse, Fort Collins, Colorado 80523

Utah State University Press, Logan, Utah 84322

(C) 2021 by Asao B. Inoue. This work is licensed under a Creative Commons AttributionNonCommercial-NoDerivatives 4.0 International license.

ISBN 978-1-64215-124-4 (PDF) | 978-1-64215-125-1 (ePub) | 978-1-64642-224-1 (pbk.) 978-1-64642-237-1 (ebook)

DOI: $10.37514 /$ PER-B.2020.1244

Produced in the United States of America

Library of Congress Cataloging-in-Publication Data

Names: Inoue, Asao B., author.

Title: Above the well : an antiracist argument from a boy of color / by Asao B. Inoue.

Description: Fort Collins, Colorado ; Logan, Utah : The WAC Clearinghouse | Utah State

University Press, [2021] | Series: Perspectives on writing | Includes bibliographical references.

Identifiers: LCCN 2021016038 (print) | LCCN 2021016039 (ebook) | ISBN 9781646422241 (Paperback) | ISBN 9781646422371 (eBook) | ISBN 9781642151244 (PDF) | ISBN 9781642151251 (ePub)

Subjects: LCSH: Language arts--United States. | Language awareness. | Racism in language. |

Violence in language. | Discourse analysis--United States.

Classification: LCC LB1576 .I634 2021 (print) | LCC LB1576 (ebook) | DDC 372.6--dc23

LC record available at https://lccn.loc.gov/2021016038

LC ebook record available at https://lccn.loc.gov/2021016039

Copyeditor: Karen Peirce

Designer: Mike Palmquist

Series Editors: Rich Rice, Heather MacNeill Falconer, and J. Michael Rifenburg

Consulting Editor: Susan H. McLeod

Associate Editor: Jonathan P. Hunt

Cover Photos: Asao B. Inoue. Used with permission.

The WAC Clearinghouse supports teachers of writing across the disciplines. Hosted by Colorado State University, and supported by the Colorado State University Open Press, it brings together scholarly journals and book series as well as resources for teachers who use writing in their courses. This book is available in digital formats for free download at wac.colostate.edu.

Founded in 1965, the University Press of Colorado is a nonprofit cooperative publishing enterprise supported, in part, by Adams State University, Colorado State University, Fort Lewis College, Metropolitan State University of Denver, University of Colorado, University of Northern Colorado, University of Wyoming, Utah State University, and Western Colorado University. The University Press of Colorado partners with the Clearinghouse to make its books available in print.

In 2012, University Press of Colorado merged with Utah State University Press, which was established in 1972. USU Press titles are managed as an active imprint of University Press of Colorado, and the Press maintains offices in both Louisville, Colorado, and Logan, Utah. 


\section{CONTENTS}

Antiracist Endowment ........................... vii

Acknowledgments . ........................ ix

Foreword $\ldots \ldots \ldots \ldots \ldots \ldots \ldots \ldots \ldots \ldots \ldots \ldots \ldots \ldots \ldots \ldots \ldots \ldots \ldots \ldots$

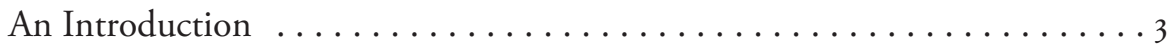

Chapter o. Language, Politics, and Habits ................ II

Chapter I. Literacy Is (Not) Liberation. . . . . . . . . . . . . . . 29

Chapter 2. The Yin-Yang of Literacy. . . . . . . . . . . . . . 37

Chapter 3. Racializing Language and Standards ............... 59

Chapter 4. Race-Judgements and The Tacit Language War............ 9I

Chapter 5 . The White Language Supremacy in Judgements of

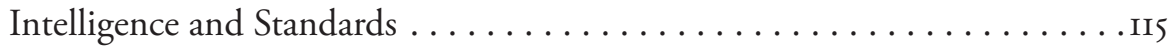

Chapter 6. The Economics of Racism. . . . . . . . . . . . I45

Chapter 7. A Languageling of Color. ................. I6I

Chapter 8. Unsustainable Whiteness .................. I79

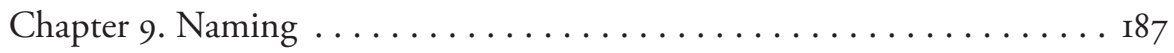

Chapter Io. I Ain't No Horatio Alger Story . . . . . . . . . . . . . . 209

Chapter II. Another Ending, or Let Me Say This Another Way .... . . . 24I

Appendix. An Argument and Method for Deep Attentive Reading. . . . . . 253 



\section{ANTIRACIST ENDOWMENT}

In the past, I have made it a practice to provide my books for free online and refuse any royalties. I've said I'd rather be read than bought. My rationale was that knowledge belongs to everyone, that it is more ethical and antiracist to make my scholarship openly accessible, at least online. Even when my books have been published in print, , I have not taken any royalties. I wanted it to be clear that my motive and agenda for writing a book and offering it to others was not tainted by profit, at least from my end.

I could have this philosophy due to Mike Palmquist and the WAC Clearinghouse's innovative model of academic publishing that offers their books free and open source for anyone to download in PDF or ePub editions. The printed editions of the books are priced low, with the goal of covering the cost of copyediting and production. Most don't cover those costs. Some do. And a few, including my other books with the Clearinghouse, actually make a profit. Those profits are put toward the cost of publishing new books.

This book, however, is not provided free or open source initially. This is so that a profit can be made and used to fund an endowment for antiracist teaching and assessment purposes. All of my profits (Asao Inoue) and all of those of the WAC Clearinghouse will be directed to this endowment, the Asao and Kelly Inoue Antiracist Teaching Endowment, which we have started at our alma mater, Oregon State University, the place where my wife and I met and where I started teaching writing. I want as much as possible of the money made from this book to be used to further antiracist educational goals, which may be training for new teachers, scholarships, establishing conferences, or other projects. Time will tell what antiracist educational work we can do through the endowment.

This is why this book has a monetary price, but only for a few years, then the electronic versions will be free, just like my books before this. And, of course, all profits from printed versions at that time will always go to the antiracist endowment. To be clear, after the costs of printing each book are recouped, $50 \%$ of the profits will be retained by the University Press of Colorado, while the other $50 \%$ will go the Antiracist Teaching Endowment. My hope is that this practice will offer not only a way to create an endowment for antiracist educational purposes but also a model for other academics and writers to accomplish other social justice work in the world.

Please know that your money paid, or donated separately, to access this book goes to a good cause. It does not go to me, the author, or to the WAC Clearinghouse. We make no profits from the sale of this book. Instead, I use this book 
as a way to give back, to move forward, to write our mutual antiracist future together as antiracist educators and students.

To learn more about the Asao and Kelly Inoue Antiracist Teaching Endowment, for details and links see the WAC Clearinghouse page (wac.colostate.edu/ books/perspectives/above), my website (www.asaobinoue.com), or the direct donation page at www.osufoundation.org/Inoue. The endowment is managed by and housed at the Oregon State University Foundation. 


\section{ACKNOWLEDGMENTS}

Writing a book requires the help of many people. I'm grateful to many who have contributed in a variety of ways in my life so that I might spend my time and labors on this book. All the people in my life are important, and I doubt I can recognize everyone. My apologies for missing many. First and foremost, I am grateful and humbled by my wife and partner, Kelly Inoue, for all that she does each day to give me the freedom to write, read, and think. She feeds my belly, my soul, and my heart. I am also grateful for my twin brother, Tadayoshi L. Inoue. I am lucky to have had a brother like him in my life from the very beginning. Not many people can say they have such a steadfast life-partner, confidant, and twin. I'm also deeply grateful for my mother, Dixie Peterson. My mom is the hero in my childhood story; she is strong, determined, loving, kind, and often sacrificing for her family. She was and is the strongest person I know, and she gave me wonderful gifts of heart, mind, and words. I have no way to repay her. I love you, mom.

I am thankful for the blind reviewers who took the time to read an earlier draft of this book and give me copious feedback. I'm humbled by not only their time but the praise they offered and the ideas that contributed toward the final version. I want to thank Mara Grayson for her reading and encouraging words. I thank Mark Blaauw-Hara for his thoughtful and compassionate feedback on the earlier draft; his insightful remarks were encouraging and offered critical considerations that helped me think through a few ideas. His feedback is the kind I strive to give to others.

Of course, the later chapters are a kind of acknowledgement to two mentors in my life, Chris Anderson and Victor Villanueva, both important to my story and to this book. I am thankful to Chris for opening the door to the academy to me, encouraging me in my nascent moments as a scholar and teacher. I am also thankful to my academic dad, Victor, for his reading of an earlier draft that helped me shape the manuscript for review and for his indefatigable guidance along my journey, which continues today. I strive to be like him in all my work and mentoring, turtles on posts.

I have been lucky to have a small group of former graduate students, all of whom now are successful high school teachers and university professors. They come from my days at Fresno State, and I'm honored and grateful to have their confidence. I'm thankful for their reading and feedback of an earlier draft of this book. Thank you to Donny Garcia, a wonderful teacher and thoughtful reader; Andy Dominguez, aka. "Pirate Andy," who always has smart and interesting insights to offer; Tyler Richmond, a soft-spoken, careful, and smart reader; Matt 
Gomes, a little quirky at times but always has interesting ideas to contribute; and Shane Wood, a hard-working, honest, and compassionate man who gave me copious feedback on an earlier occasion too. These are the "Rhet-Comp Dudes," a group that re-formed after years apart. During the pandemic summer of 2020, the Rhet-Comp Dudes Zoomed together to talk teaching, research, and our writing. We started with this manuscript. I'm grateful for them and the time they gave to my draft.

Finally, I thank the editors at the WAC Clearinghouse, Rich Rice, Heather Falconer, and Michael Rifenburg, for their good work and continued confidence in me. In particular, I'm grateful to Michael Rifenburg's careful reading of the reviewers' comments and thoughtful synthesizing of that feedback, which helped me prioritize my revisions. And last but by no means least, I am humbled and grateful for the labors and support of Mike Palmquist, the founding editor and publisher of the WAC Clearinghouse. I cannot imagine publishing a book without him and his unfailing support and keen judgement. He's a friend, a colleague, and just about the best publisher around that I know of. 


\section{FOREWORD}

Thoughts upon reading Above the Well.

Wake up in the middle of the night. A bathroom run. Don't turn on the lights, stub a toe against one of the bed's legs, bump a shoulder against the door jam, even though the doorway is four-foot wide and I'm not.

I've got stereoscopic vision, yet I'm not always conscious of using this gift. And I bang up against the edge of the door.

And then there's the light switch.

Forget about why I didn't turn on the light. Might have been a good reason (not wanting to disturb my mate in the middle of the night). Here, I'm thinking about how that light switch came to be.

We've been told about Benjamin Franklin and a key and a kite, harnessing electric power (and leading to the lightning rod). And we've been told about Thomas Edison and the electric lightbulb. And there were others, of course (but of course, we mainly learn of the Americans). But consider the conversations that led to General Electric, the first electric company. It took folks we would think of as scientists and engineers and manufacturers agreeing to work together, to be convinced, to cooperate. And it would take convincing a wealthy man, J.P. Morgan, to invest in the making of General Electric.

What I'm getting at with all of this is that we have a biological predisposition for language, the gift of language, maybe greater than the gift of stereoscopic vision, since no other creature uses language the way we humans do, but we're not always conscious of our uses of language. When we do become conscious of those language abilities we enter the world of rhetoric. Without our ability to cooperate through the negotiations made possible by the conscious use of language, by rhetoric, none of the great wonders of the world, the wonders of architecture, science, technology—none of it—would be possible. It all begins by our working together through language.

But in saying that, there is the presumption of cooperation. Yet "cooperate" is a tricky word, because it assumes equal power. Neither Edison nor his friend Henry Ford despite their abilities to create and to convince others of the value of their creations still needed the power of money. They had to sell their ideas to those of great wealth. And less recognized would be the women and the folks of color who helped to produce the lightbulb, motion pictures, the auto industry's assembly line. 
What Dr. Inoue provides is some ways to think about rhetoric and power and the languages that come into play in the creation of workable rhetorics. His is not a linguistic study, it is a rich rhetorical study.

Another thought.

There was a time when Martin Joos's The Five Clocks (1967) was commonly read as an introduction to linguistics and as a discussion on "usage" (the ways language is used by native speakers of that language). Using the metaphor of clocks, he places the "norm" in English as "Central Standard Time," and he questions it. He writes,

English-usage guilt-feelings have not yet been noticeably eased by the work of linguistic scientists, parallel to the work done by the psychiatrists. It is still our custom unhesitatingly and unthinkingly to demand that the clocks of language all be set to Central Standard Time. And each normal American is taught thoroughly, if not to keep accurate time, at least to feel ashamed whenever he notices that a clock of his is out of step with the English Department's tower-clock. Naturally, he avoids longing aloft when he can. Then his linguistic guilt hides deep in subconscious mind there secretly gnaws away at the underpinnings of his public personality. ... [I]n his social life he is still in uneasy bondage to the gospel according to Webster as expounded by Miss Fidditch [the English teacher]. (4)

That was written in the nineteen sixties. Dialects and racism don't enter into his writing. He is busy saying that there's nothing natural about the language of power. So that since Joos, we have espoused the viability of various dialects and have argued the "Students' Right to Their Own Language" (College Composition and Communication, vol. 25 Special Issue, 1974). Yet that gnawing away of "correctness" lingers—-maybe even especially among students of color and the bilingual (more than the polylingual) attempting college. And the good-hearted tutors at the writing center reinforce the mentality, even if kindly, and the good professor, wanting his and her students to succeed will reinforce it, even as speaking of dialects and the like. We recognize that standing before a wave with our hand up yelling "Stop!" cannot stem the tide of standardized conventions. We can't help but recognize the power at play. Inoue recognizes that if there is power, that power cannot help but be racialized. It's not simply the conventions of a disassociated dialect of prestige, but that prestige and power belongs to a 
certain class and its racial power. Not just a standard, but a symbolic imposition of what he calls a "white language supremacy."

Dr. Fidditch-two instances.

A graduate student and teacher, a woman of color, emails. A student had asked if the southern dialect is also an instance of white language supremacy. I respond:

The answer to your student (great question!) is yes and no. No. The regional dialect of the South and even the southern Midwest (which is different) and the Southwest (especially Texas) are not the prestige dialect (which is how linguists have described it for years). And historically, the dialect of the southeast came from Black folks (who raised the wealthy white folks as "mammies" and "aunties" and "uncles"). And those Black folks got their dialect from a mix of their native tongues, mixed with the lingua franca of slave trade, West African English Pidgin, and the "accent" of the task masters (not the Masters who lived in the Big House, but the guy who was like a foreman in a factory, the guy with the whip). The task masters were Irish (when they were still considered racially inferior though above the Black slaves). BUT since regionally there is a middle-class white southern dialect, it becomes a localized white language of supremacy. We've had presidents with a Texas accent (Johnson) or a Southern accent (Carter), so the power is the power even if the northerners wouldn't recognize their dialects as the dialect if white language supremacy. See? ... I prefer Standardized American English-not "standard," which is the linguistic term for the oral, but since it's a social construct, standardized. Now, one last complication. There is no southern accent in written discourse. If it weren't for a few words (like colour or honour or referring to a lorry instead of a truck), we wouldn't know a southerner from a northerner or a Canadian or a Brit or an Australian from an American. So in written discourse, what linguists call Edited American English, the written "standard," there sure is a discourse of power (which is what Asao is getting at). But even that gets messy. EAE doesn't have to be academic discourse. Asao is using that language. I use that 
language. So do you - and we ain't white. But we recognize the power in the prestige dialect.

So-yes, in the south, the white southern dialect would be a "language" of white supremacy (you know, the language is English, more a matter of Imperialism). But outside of the south, no, not really (northerners and midwesterners and westerners denigrate the dialect). But in writing there is no "southern dialect." There's only the standardized and its conventions, which have been imposed by those in power-white folks. That help?

I got pedantic. Couldn't help it somehow. The thing is, what Asao provides and demonstrates and discusses isn't really a matter of linguistics. It's a matter of power. It's a rhetoric - it's the stories of accommodating and of resisting the rhetoric of power, white language supremacy.

\section{Example two.}

I read Asao's manuscript-more than once. I had a habit-each time and over many years — of pointing to his spelling: judgement. As you will read in what follows, Asao talks back. He has his logic. It makes sense. And after all, the British standardisation (with an -s rather than a $-\mathrm{z}$ ) does spell it as judgement.

But here's where bilingualism (even as what is known as a "heritage speaker," someone able to hear with a ready bilingualism but feels anxiety in speaking the first language, which is my case) comes into play as the "gnawing away of 'correctness'."

Our writing system (and I mean the alphabetic system) is based on the oral. It's what is termed a phoneme-grapheme correspondence. The sound effects the graphic, the writing. Now, in English the correspondence sometimes falls apart because of English's long written history, so that knight is pronounced nite rather than its original kuh-nikt. The first sounds that met my ears were Spanish, but the first writing I did was in English, when I entered school. I had to learn the sounds of English (a New York and Black English until I was sixteen and very consciously learned Central Standard Time). I learned the sounds and was taught spelling using phonics. The phoneme-grapheme correspondence was rigid for me. Since I knew that the spoken dropped the final -r (in New York), I would write that a thought was an idear (which when I was twelve, the president of the U.S. would say too, John F. Kennedy's Boston dialect). Even when it came to the language of the streets, I would not hear gonna (the written con- 
vention for going to) but gone ("I gone tell ya what!" when pushing back against a challenge). I was in my twenties when I discovered (or, more precisely, was mockingly told) that the brow was not pronounced for-eh-head. So I cannot see judgement and not say in my head judg-eh-ment. I still subvocalize as I read. And that is my problem, a problem with usage from which Asao breaks free. He owns his language, does not kowtow.

Because of the imperative to learn English, imposed by my parents (who gave me the duty of teaching them English), imposed by the school (Sister Fidditch), and imposed by society, I am compelled by the need for a kind of precision. I remain subject to "English-usage guilt-feelings." Asao, throughout the book, and in the example of this one word, judgement, breaks free of any guilt, and in so doing allows us all to break free.

I have to be very conscious to resist white language supremacy, to the degree that that's possible, more so than Dr. Inoue, apparently. I very rarely turn to dialect in my writing. My youth was Spanish and Spanglish and what linguist Ana Celia Zentella calls Puerto Rican Black English. But if TV can be a guide (and I think it can in this case), that dialect sounds very different now, nearly sixty years later. I fear I'd sound like someone mimicking a dialect that I no longer own. But I can and do turn to the rhetoric of my upbringing and my ancestry. In the language of rhetoric, as Asao will explain, I employ the rhetoric of the Sophists more than Aristotle. The language might be the language of the power of those in power, but my use of it pushes back against that power. And that is true of Asao's writing.

All this brings us back to what we will discover and learn as we enter this work by Asao Inoue. His history is not mine. We might both be what Asao calls languagelings, but we arrived at our ways with words differently, even with different commonalities, given differences in time and place and "color." His is the history of the working class, the history of an American of color, a mixed-race Asian American. And just like even an octaroon (someone one-eighth Black) remains Black or a "high yella" or a "redbone," what is clear to those who come in contact with Asao is that he is not white, confused, as he tells us, with a Latino. Even as he is a champion reader in elementary school, he is a champion reader who is nevertheless regarded as having a language deficiency. What folks see affects what they hear. We will learn of the ways in which racism is never not tied to language, its use, its power-even when the power is on his side, as in the "language" he shares with his twin brother Tad (who sounds so much like Asao, even down to Asao's linguistic idiosyncrasies, that it's uncanny). "Twin Language" still becomes subject to white language supremacy. We travel with 
Asao through grade school, the southwest, the Pacific Northwest, colleges, the Midwest and the ways in which racism is always vying for power and must be challenged. Autobiography, theory, teaching, philosophy, theology—all are beautifully interwoven. And always there is power.

Enjoy the journey in the pages ahead. And with Asao Inoue consider how we might assume our own power.

Victor Villanueva

Pullman, WA

22 November 2020 


\section{ABOVE THE WELL: \\ AN ANTIRACIST LITERACY ARGUMENT FROM A BOY OF \\ COLOR}





\section{AN INTRODUCTION}

Our language participates in racial violence. That is, we are all enlisted, whether we like it or not, into an invisible and very deadly racial war waged around us daily. That's too much to tell you this soon. Let me come back to this in a few pages.

Years ago, I was introduced to an elder's wife in a church that my wife, two sons, and I were visiting. We thought we might join that church. We had just moved to town. It was my first professor job after getting my Ph.D. We were in an unfamiliar place, southern Illinois. The elder's wife, an older, White woman who spoke loudly, was greeting us in the foyer. It was our first visit to the church. She asked our names. I said, "My name is Asao Inoue. This is my wife, Kelly, and my sons, Kiyoshi, and Takeo." She replied, "Well, you don't make it easy." I didn't know what to say, except to smile awkwardly at her and never go back to that church again.

In many ways, this anecdote is symbolic of my literacy journey, of what you may find in the following pages. I know that the elder's wife did not mean to be unkind or unwelcoming, but she was. She didn't mean to insult me or my name or my heritage, but she did. She didn't mean to open a wound of mine that was inflicted when I was seven or eight years old, but she did that, too. Should I have given her and that all-White church another chance? Maybe, but why is it that in such exchanges that involve race and language, it is the person of color who must always do the forgiving, who must always overlook the faults and missteps of the White people around them?

I don't mean to lay all of the blame on that White woman's shoulders. She wasn't trying to be mean or racist. She's really just a symptom of racism in our society, not the cause. She likely lived her entire life in the Midwest, in southern Illinois, in communities of mostly, if not completely, White people like her. She most likely had never confronted her own racial positioning or considered how her words were tied to the community she came from. Her environment never asked her to, never showed her clearly her own Whiteness. She likely was always an insider. She was a product of a culture that allowed her to think that making fun of someone's Japanese name was okay, that jokes are just jokes, words just words, that race and our histories of racism don't factor into her words or our names. She didn't mean to be racist in conditions that make racism.

Race is a set of structures that make up our lives. Language is one of those structures. Language and names are conjured in groups of people who use their language together. In this seemingly innocent exchange that was ostensibly about being welcoming and learning our names, this White lady could not see how salient race is to our use of language and the judgements that language is 
interlaced with. ${ }^{1}$ In one sense, this book attempts to illustrate just how salient race is to language, judgement, and our attitudes towards language and people around us who use it. ${ }^{2}$

Let me be clear. This book is for students of language. I don't mean just for school purposes, but for anyone who wants to learn about the connections between language and racism and who are not researchers or scholars of language, just regular people interested in this thing we do together, language, and in stopping the racial violence in our world. In many ways, I envisioned a first-year college student audience or a high school senior as I wrote this book. I try to open up the kinds of discussions about language, judgement, and racism that I have with first-year college students in my writing courses.

I am not offering a memoir. This book is not a straight narrative of a boy's coming to his own literacy. In fact, I resist rehearsing a coherent or chronological narrative of my schooling or of my learning to read and write, so you may resist how I've written this book. We have plenty of books about Brown and Black kids who made it or didn't. You don't get to pity me or be amazed at all that I have done. That's not my story here.

In my experience, those kinds of literacy narratives, as useful as they are in many ways, also too often are an excuse for White readers to wallow in the exotic, to feel pity and sadness for the poor Brown kid, then feel good about how they feel about racism because they felt good about sympathizing with the Brown or Black author. Those narratives often mingle the pathos of the writer of color with what that writer is offering as analysis, critique, or solutions to racism or White supremacy. And when it comes to race and Whiteness, White readers often have difficulty with all these things for some valid reasons, which I'll get into.

White readers too often act as if rooting for the Brown kid, being on his side, is enough. It is not. You must do antiracist work, as Ibram X. Kendi has ex-

$1 \quad$ I spell this word "judgement," realizing that the more common way to spell it is "judgment," with only one "e." I do this because, well, it looks better to me, complete. It's my languaging. It also preserves in a visual way the operative word, "judge," with the implications of an agent who has their own perspective, a judge with a singular view of things. Judgements do not just happen. They come from a judge who "judges." A judgement is the end of an action. I'm preserving the noun and verb in my word. I like to keep all of these meanings visualized and represented in the word on the page. And if it bothers you to read it this way, that's one of my points in this book. It should also be noted that this is the common British spelling of the word, but I'm not using this spelling to favor that standardized spelling over an American one.

2 I take this idea of saliency from Robin DiAngelo. She says: "We all occupy multiple and intersecting social positionalities. I am White, but I am also a cisgender, woman, able-bodied, and middle-aged. These identities don't cancel out each other; each is more or less salient in different contexts." See, Robin DiAngelo, White Fragility: Why It's So Hard for White People to Talk About Racism (Boston: Beacon Press, 2018), xvi. 
plained. ${ }^{3}$ It's not enough to just feel for other's misfortunes and abstain from racism. We must act in different ways and change the structures in our lives that enable us to act or stand by and watch. The structures I mean in this book are those that maintain acceptable language in schools and public spaces- that is, what we often call, "Standard American English," "Dominant American English," and what I call "Standardized American English." More on this later in the book, too.

Our habits are often strong, comforting, even when they hurt us, or do not help us. It's hard to give up a habit-say smoking, or eating too many sweets, or saying "like" in front of every other sentence, or smiling when you are nervous. In many ways, this book is about habits of language that become our ways of communicating and judging words and people. This book is also my literacy story. It describes some of the important things that made me into the languageling I am today.

But this book is not simply a story about a poor Brown kid from the ghetto who made it out and up. It cannot be. It is also about the ways we all participate in the White language supremacist systems and conditions that we work, live, and do language in. It is about our names for things and people, about the race-judgements we make in and through our language that we may not know we are doing. It's about the economics of race that affect our languaging. It's about the Whiteness in language and how I'm not a good example of how great our systems are.

This book will not give you a linear narrative or chronological story of my life or education, yet paradoxically you can find that chronology in these pages if you wish to piece it together. I will not always engage in the habits of language that you likely expect in stories like this one. Even if you can't say exactly what those expectations are, I guarantee that you will feel them when they are broken in books like this. I'm hoping many of my readers will notice this about their own expectations and habits of language. I hope you will feel your expectations broken. This is one small stone in the path to antiracist languaging.

For instance, I ain't gonna always write whatcha call Standard American English all the time. I will not always give you an experience about myself then interpret that experience or make sense of it for you. I may reverse that order or skip one part, or I may use it. I am not going to tell you a story about me only, as if doing that would explain my languaging.

These kinds of common expectations in books like this one are the habits of the English language that I'm trying to critique, trying to understand with you as I tell my literacy story. So I may use them, because that's my training in school, but that ain't the only way I language. Like you and many others, I too

Ibram X. Kendi, How To Be An Antiracist (New York: One World, 2019). 
have a hard time imagining what language is like—or what it could be-outside of these standardized ways of doing it. I'm not above these common habits of language, these habits of White language (more on that later, too). No one is. But I'm trying to work around them as much as with them.

So, what is my method in this book? There is a scene that I'm trying to show, one that has no central actor, and yet I am the subject of this literacy narrative. But it ain't just my literacy narrative. It cannot be. To understand my literacy, I need to drop myself onto a landscape with lots of other interesting people, ideas, and topography that I want you to know next to me. You should know about Freire and Western and Taoist dialectic differences in habits of language, know about the economics of racism, about textbooks and my experiences, about naming in other places I've never been, and about Horatio Alger. I want you to know all these things so you can simulate an orientation to language like mine, so you can come close to knowing me and my languaging as I do. You'll miss too much if you focus just on my schooling, or my reading history, or my story. Furthermore, why should I talk just about me, yet how can I talk about anyone else?

My opening scene above is a good example of this tension. It seems so natural to start a book about my literacy journey in this way. So many other books start in similar ways. I start with me and my name, an experience you, my reader, can see and connect with. A good way to start a story about literacy is with a story about names and language, right? Now, what I'm describing is a set of language habits that are so ingrained in English language users that they can seem natural and right. If I did something else, you may not find my book worth continuing past the first page. You may think I'm not a good writer. You may think I got bad editorial advice. You may wonder: How is this a story about this guy's literacy or education? These judgements come out of White, middle- and upper-class, monolingual English language habits that I want to call attention to in this book. Why? Because they make up many of our literacy stories and they hurt so many, particularly when they are used in society as universal standards and used to withhold opportunities and rewards.

So, part of my reasoning for how I have written this book is to help readers escape from a false sense of knowing about "good" language and its "appropriate" standards. Another part is about understanding our feelings about language that influence our judgements and expectations of people and their words. And another part is about understanding racism and the White supremacy in our literacy practices. What I aim to do is disrupt your expectations about how such stories of literacy like mine are told by disrupting what you think learning English means and what it takes to understand it in any of us.

In many places, then, my discussion will sound less like a story of my experiences and more like an exposition of other things, an argument. In those 
places, it may sound like a discussion of education, history, language, testing, economics, or race in the US. And that is because it is. I don't think I can tell my story of learning to read and write without telling a larger story of language and judgement in the US, even if only in parts. Who I am, and how I use language, what I think of that language, is connected to many other things in the world, in my life, in history. And most of these larger things, I do not control. And for many of us, they are invisible. I want to make them more visible.

Some of these things, these structures, are economic and governmental systems. Others are narratives and ideas in U.S. culture that are interlaced with language and ideas about language, which often seem to be about other things, not race. For instance, the notions we have about how a smart person talks - that's a set of structures, narratives, and ideas that we use to make decisions about things and people. And those structures about what smart sounds like are connected to lots of other structures, like economic, geographic, and educational systems, all of which no single individual controls. So my literacy story, like everyone's, is also a story about larger systems in place that we all live in and shape us in different ways. My story of literacy, like yours, is really a story of structures, of systems that make me, and that now I try to remake.

It is often more comforting to believe that we are in full control of who we are and how we use the languages we do. This allows us, especially teachers and bosses, to blame others for not communicating in ways we think they should. Thinking you have full control of your languaging means that when someone else thinks you don't language well, it's your fault. And while I do believe we have a lot of control over who we are and what happens in our lives, I do not believe we control all of it, nor do I think just anything is possible for every person.

There are boundaries and limits to what we can do, and those limitations are not the same for everyone. I'm not saying that some people are inherently less than others. I'm saying people commune and live among other people in groups, and these groups have different relations to the systems we all work in. Those relations to systems matter because they create walls and doorways.

It is the systems in place, like schools, civic life, economic markets, governments, churches, even our systems of language and standards for language that make the conditions of our lives. These systems create and structure what is possible for us and how our own words will be valued or heard or understood by others. Thus, what is possible for any given person is not equal. That White elder's wife was a product of White supremacist systems just as much as I am, as we all are. And the question I want to ask through my own literacy narrative is this: How do we come to understand the White language supremacist conditions in our lives in order to remake those conditions for a more equitable, antiracist, and better world? 
Now, let me come back to my opening statement. Language participates in violence. This is the reason I write this book now in this way. It's the exigency for this book. It's also a tacit argument for teaching languaging in writing classrooms in ways that matter to our lives, not just to arguments, to bodies in the street, but I won't make the explicit teaching argument here. Teachers will have to figure that out, just as other readers will have to figure out why this kind of book is important at this moment in our world. But in or out of the classroom, we all are fighting an invisible racialized war on the battlefield of words. And what's at stake is White language supremacy.

As I write this introduction, there are numerous protests, rallies, and activist groups across the US, even in other countries, demanding that police violence against Black bodies stop, that local governments defund their police departments, that they invest in community policing and programs that help and nurture Black people, not treat them as criminals first, which then justifies any violence done to them, including killing them. These widespread protests have come after the brutal and indiscriminate killing of George Floyd by a White Minneapolis police officer while other police officers stood guarding that officer as he slowly choked Mr. Floyd to death.

While Floyd was being killed in front of a group of people, some recorded it on their cell phones. One video captured Floyd begging in a weak choking voice, "Please, I can't breathe." The video quickly went viral and sparked the protests. It is traumatic for many Brown and Black people, like me, to watch. I have actually not watched it in its entirety. I can't. It's too painful. One reason is that this is just one of the many killings of Black citizens in the US by police for no reason. It is a synecdoche of many, many other police killings and violence against Black bodies in the US. It's one killing that reveals the many others before it. The protests wouldn't be so numerous, loud, and ubiquitous if this kind of racialized violence weren't a long, historical, and racialized pattern. It's one way White supremacy occurs.

How could a police officer, charged to protect and defend citizens, do such a thing? What conditions create such killing, such disregard for a human life? What orientation to the world and words must it take to ignore a begging, choking, dying Black man in front of you? How could his words not be heard by that White police officer, or any of the others? This book, my literacy story, aims to explain why. So I hope you will bear with me, sit in some discomfort (if you feel it at times), and take the full journey with me.

One of the central themes about language in this book is that words have real effects on us, emotionally, physically, even spiritually. They are more than logos, than reasoning, more than terms and ideas. The ancient, fifth century (BCE), pre-Hellenic (Greek) philosopher and teacher of orators, Gorgias, named this language phenomenon as magical. He said, 
Speech is a powerful lord, which by means of the finest and most invisible body effects the divinest works: it can stop fear and banish grief and create joy and nurture pity. ... Fearful shuddering and tearful pity and grievous longing come upon its hearers, and at the actions and physical sufferings of others in good fortunes and in evil fortunes, through the agency of words, the soul is wont to experience a suffering of its own. . .. Sacred incantations sung with words are bearers of pleasure and banishers of pain, for, merging with opinion in the soul, the power of the incantation is wont to beguile it and persuade it and alter it by witchcraft and magic. ${ }^{4}$

I think it is important to notice how words work on us, how they make us and our emotional responses to others and their words. Because language can have such magical effects on us, like witchcraft, beguiling us in various ways, it seems prudent to notice, to pay attention when it happens and that it does. I offer a short appendix essay at the end of this book that discusses a method for reading that I think may help you see the magic in words as you read. I call the practice deep attentive reading, and it can be an antiracist reading practice.

Furthermore, our emotions and understandings have a relationship to one another, often in ways we may not realize or want all the time. In his Pulitzer Prize winning novel, House Made of Dawn, N. Scott Momaday speaks of a grandmother and her languaging: "her regard for words was always keen in proportion as she depended upon them . . . for her words were medicine; they were magic and invisible. They came from nothing into sound and meaning. They were beyond price; they could never be bought nor sold. And she never threw words away." If you have magic, you don't throw it away. You pay attention. You respect it, tend it, take special care of it, perhaps give it as a gift to others. We all do word magic. We just don't always realize it. We have a responsibility to pay attention.

But if we aim to be antiracist and anti-White supremacist in our actions and words, if we hope to stop the racial violence around us, then we should acknowledge the magic in words, how they are also tacitly racialized, how they work on us in invisible ways, how they limit and bind us, how they do violence as much

4 Gorgias, "Encomium of Helen," in The Rhetorical Tradition: Readings from Classical Times to the Present, 2nd ed., ed. Patricia Bizzell and Bruce Herzberg (Boston: Bedford/St. Martin's, 2001), 45.

5 N. Scott Momaday, House Made of Dawn, (New York: Harper \& Row, 1968), 95-96, quoted in Thomas King, The Truth About Stories: A Native Narrative (Minneapolis: University of Minnesota Press, 2003), 100. 
as attend to us in loving, compassionate, and medicinal ways. And of course, no one is above the magic of words, no one is above their own language conditions. If these conditions are White supremacist, then we all have responsibilities to attend to and tear down these systems and rebuild better ones. 


\section{CHAPTER 0.}

\section{LANGUAGE, POLITICS, AND HABITS}

Why is there a chapter 0 ? I think it is important to establish a few definitions and key ideas that I draw on in the rest of this book. These terms may be triggers for some readers. I don't want them to be. I want them to be terms that help us engage together, perhaps engage through our disagreements. This chapter is important because it helps me tell my story better, and it must come first.

Let me give you an example to help explain. Imagine you are trying to have a conversation about going to Los Angeles with someone you care about, someone you respect, say your sister. You believe that both of you would have a great time, be enriched in a number of ways, if you both took a trip to L.A. Your sister, let's call her Angelica, doesn't like L.A., won't even talk about it. Now, every time you mention the topic, or even say "L.A.," you can see her face crinkle up, her eyes narrow, and her mood become sour and angry. She gets upset about it.

She had a really bad experience in L.A. ten years ago. She never wants to go back, and even talking about the city reminds her of that terrible event. But you have good reason to think this time will not be like that last one. Things are different, better. In fact, you have made extra efforts to ensure that your proposed L.A. trip with Angelica will be really great, nothing like her last one. But she just won't listen when you bring it up. You can't even get to the details. She turns and goes away or focuses in on how the details she does hear are just like the L.A ten years ago, the bad L.A.

So your job, if you really think that trip is worth it, is not to convince Angelica about how good the trip is or will be, or how her last trip to L.A. was a fluke, an unlucky set of occurrences, or simply a long time ago. Your best shot at convincing her likely will be to help her through her emotional response to the idea of L.A., not to change her mind, but to help her deal more productively with those emotions and see how they may be keeping her from hearing new details, a different L.A. You have to help her hear details that may be different from her initial ideas.

This kind of problem is what I think many people have with the terms that I explain in this chapter, like White language supremacy. Angelica is missing out on a really great trip and a great city, but she's also right. Her experiences were awful, a good reason not to go back. But if she can't confront at some point those past experiences and her emotions about them and find a way through it 
all—that is, if she can't sit with difference meaningfully—she is limited, and her limitations are self-imposed. She imposes a boundary on her life that excludes L.A., a place that is bound to offer her something rich, even if she never goes on the trip. This chapter, I hope, helps some readers who might be in Angelica's position around issues of racism and White language supremacy. These ideas are vital to my story in the rest of this book.

Now, should you find that you still have trouble reading, trouble accepting ideas, even just entertaining them long enough to hear what I'm saying, you might read my appendix, "An Argument and Method for Deep Attentive Reading," which I mentioned in the Introduction. That stand alone essay offers a compassionate reading practice that I think can help. I know it has helped me.

The essay also offers a more detailed discussion of several key ideas that I reference throughout the rest of this book, namely, the availability and WYSIATI heuristics, confirmation bias, and the halo effect, all of which Daniel Kahneman discusses and that keep many people from considering seriously different ideas or arguments from those they already hold. ${ }^{1}$ These are mindbugs we all have that Banaji and Greenwald also explain. ${ }^{2}$ They are ways our brains often think too fast and in the process make faulty judgements. And they are implicated in racism and my literacy story.

\section{WHITE LANGUAGE SUPREMACY}

"White language supremacy" is a term that can conjure up some ugly feelings. The words "White" and "supremacy" in the same phrase often trigger many people, particularly White people, because it can sound like I'm calling all White people racist, or I'm placing evil intentions on all White people, but I'm not. I'm not even referring to people's intentions or attitudes when I use this term. This misunderstanding is reasonable in the US today, since historically the phrase "White supremacy" is connected to bad people doing and saying bad or racist things, like enslaving and lynching Black Americans, imprisoning those of Japanese and Arab descent into "internment camps" or "detention centers," or turning high-powered water hoses onto innocent people.

While certainly the kind of White supremacy I'm speaking of in this book is historically related to that kind from the past in the US, it does not look the same today, is not accomplished in the same ways, nor is it experienced in exactly the same ways. But it is connected to our past. It is a legacy we live in.

1 Daniel Kahneman, Thinking, Fast and Slow (New York: Farrar, Straus and Giroux, 2011).

2 The concept of "mindbugs" comes from chapter 1 of Mahzarin R. Banaji and Anthony G.

Greenwald, Blind Spot: Hidden Biases of Good People (New York: Bantam Books, 2016). 
We must remember that who and what we are today is built on who and what we were yesterday. We don't escape our history because we are born from the material of history. We cannot say that we are only shaped by today's stuff or by just the good stuff of our past. We gots all of it - the good, the bad, and the other-in us. So White supremacy, as Robin DiAngelo tells us about racism, is "a structure, not an event."3

Dina Gilio-Whitaker, an indigenous scholar who studies native environmental justice, offers a good explanation of her use of the term "White supremacy" and of the anxiety around it for many people. She connects it to U.S. settler colonial history and the injustices done against native American tribes and nations and their homelands. It is worth reading her explanation at length:

Americans like to think that since the civil rights era, we have achieved the postracial, meritocratic, multicultural state where color blindness and equal opportunity prevails. Both liberals and conservatives like to think that racism is defined only by hostile behavior from which individuals can excuse themselves because they have friends, employees, perhaps an old lover or two who are people of color. In this way of thinking, White supremacy is an ideology restricted only to rogue alt-right, neo-Nazis or White-nationalist fringe groups, and certainly not well-meaning everyday people, whether conservative or liberal. While White supremacy is most definitely at the root of those regressive social movements, as a foundational worldview constructed by centuries of White European settlement of the United States, it is far broader than that. It is the thread from which the American social fabric is woven. A few decades of laws promoting racial justice have failed to unravel the systemic forms that White supremacy has taken, reflected by a range of social indicators from chronic wealth inequality to negative educational outcomes to disproportionate rates of violence (police, sexual, and domestic) and incarceration in communities of color. Centuries of dehumanization of American Indians, African Americans, and ethnic minority "others" has left its mark on the American mind and in its institutions, refusing to die. ${ }^{4}$

\footnotetext{
3 DiAngelo, White Fragility, 28.

4 Dina Gilio-Whitaker, As Long As Grass Grows: The Indigenous Fight For Environmental Justice, From Colonization to Standing Rock (Boston: Beacon Press, 2019), 99.
} 
What Gilio-Whitaker highlights is a "range of social indicators" that help us see White supremacy in our world. These indicators are conditions that are the effects of White supremacy and its cause. In short, White supremacy can be seen in the conditions that we all live in and that disproportionately hurt people of color in the US.

These conditions typically help or privilege those deemed racially White, mostly through historically made structures that are connected to or associated with racial groups and the places each group tends to live in. Such structures consist of things like language practices, family wealth, different qualities of schools in particular neighborhoods, and the different levels of police engagement and crime rates in various areas of a city. Thus, my use of this term in this book is not meant to directly reference evil people, or bad intentions, or hooded figures burning crosses, even though it is historically connected to that kind of overt racism.

The term as I use it is meant to help us remember our history, not forget it. Race, while not biological or real in that sense, is an important factor in who we are, how we use and judge language, and what we believe. Race is so interlaced in our world that we often mistake it for something else.

The terms I use are meant to remind us that we are trying to change conditions, systems, not people's minds or hearts, although changing our conditions can change minds and hearts. It takes time, though, for the new antiracist structures to do their work on us. So it's important to use these words, even if they are initially shocking or jarring, even if they make us uncomfortable, or pause, or cringe.

When we were first married, my wife and I lived with her grandma in a home in Monmouth, Oregon. My wife's father and mother and I were sitting out on the patio in the back. We were talking about the wedding a year before, how nice it was, how many people showed up. One of them, I think her mom, a selfless and kind White woman who has worked very hard her whole life, mostly for those around her, said, "They thought you were Mexican." She said the last word, "Mexican," in a half-whisper, and I thought I saw her scrunch her nose just slightly on the word. She explained that others disapproved of her daughter's marriage to me at first, that they told her this at the wedding. "You allowed her to marry him?" they asked. She said to us, "We told them that you were Japanese, not Mexican.” No whisper.

I remember how uncomfortable the conversation was, how quickly it turned, not just because race was referenced, or rather whispered, but that it was also deployed to show I was accepted into their family. I was glad she moved on quickly and politely. This was my new family. I loved them. I love them more today. I did not want to cause strife because I disapproved of how they defended me. I didn't want to call them out on the racist language they were likely trying to avoid and probably thought they were successful at avoiding. 
This is often how White language supremacy operates in our daily lives. It is hard to see and hear and even harder to talk about, to investigate. This kind of work requires conscious compassion, suffering with others, like my misguided mother-in-law, whom I love dearly. We have so few words that can help us through our racism. And yet, our words make us and unmake us. They are all we have.

White language supremacy, therefore, can be defined as the condition in classrooms, schools, and society where rewards are given in determined ways to people who can most easily reach them, because those people have more access to the preferred embodied White language habits and practices. These White language habits are so because they historically have come from White racial groups in the US who have had the power to make such standards and enforce them in schools, civic spaces, governments, and businesses. Part of the conditions of White language supremacy is an assumption in most systems that what is reachable at a given moment for the normative, White, middle- and upper-class, monolingual English user is reachable for all.

This assumption is often cloaked in narratives or justifications that use meritocracy and "fairness," such as "everyone must be judged by the same standards," without examining who tends to be most advantaged by the use of such universal standards. It seems irrelevant to consider where those standards of expression come from, who made them, and who they tend to benefit most in the present context. This assumption is also justified in arguments about merit, bootstrapping, and the idea that anyone can achieve as long as they work hard and long enough, while ignoring who tends to end up achieving the most, who usually must work harder for the same benefits or opportunities, and what prior preparation is necessary in order for someone to be able to take advantage of those opportunities.

Here's how we know White supremacy and White language supremacy exist and are vigorously reproduced in our world: look to who controls things in our society and where they come from. In her discussion of White supremacy, Robin DiAngelo offers a list of facts about the U.S. society's systems that amount to White supremacy in the key areas of education, literacy, government, business, and entertainment. Each of these areas play an important part in determining which English language standards are used, what language is normal and acceptable, and how people think about that language. Here's a shortened version of DiAngelo's list:

- Ten richest Americans: 100\% White

- U.S. Congress: 90\% White

- U.S. governors: 96\% White

- Top military advisors: $100 \%$ White 
- People who decide which TV shows we see: 93\% White

- People who decide which news is covered: $85 \%$ White

- People who decide which music is produced: 95\% White

- People who directed the one hundred top-grossing films of all time, worldwide: 95\% White

- Teachers: $82 \%$ White

- Full-Time college professors: $84 \%$ White $^{5}$

These are the judges and decisions makers in our society. They make our structures and conditions, our society. We inherit these structures and conditions, often taking them for granted. We consider them normal and neutral. At face value, they do not appear to be about race or White racial superiority. They seem like objective, race-neutral policies about language use, or about standards for evaluation and grading in schools, or about practices of reading and judging words and people. But these structures are little machines that help us do things and make things with words, like communicate or make decisions. These litthe language machines can only make particular things in predetermined ways, because that is how machines work. They are designed to produce a particular thing in a particular way. This is to say, all machines have their biases. They cannot make something else or change the way they operate on their own. Our language habits are little machines.

To make something else or make something in a different way, we have to dismantle the machine and build a new machine. This is why my definition for White language supremacy centers on conditions and assumptions, both of which are structural in nature. That is, we may not realize we are in these conditions or have these assumptions, but we operate from them nonetheless. Assumptions are thought and judgement structures we take for granted, use unconsciously most of the time because it's more efficient to do so. This is Kahneman's fast thinking. ${ }^{6}$ It's implicit racial and other biases, or the mindbugs that Banaji and Greenwald discuss. ${ }^{7}$ Thus, White language supremacy is not an intention or an expressed goal for anyone or any system; rather it is an inherited condition in society, schools, classrooms, courtrooms, boardrooms, everywhere, that determines the outcomes in these places as White language supremacist.

To see our world as White supremacist is not to say that White people have gotten things they have not worked for, that they are less than who they think they are. That's one of the paradoxes. I am making no comment on whether a

5 DiAngelo, White Fragility, 31.

6 Kahneman, Thinking.

7 Banaji and Greenwald, Blind Spot. 
particular White individual or group has earned all that they have, or are as good as the system seems to say they are. In fact, I'm willing to assume they are good and have earned all they have, but this does not negate the fact that the systems they have worked in and used to earn their rewards are White supremacist, that it helps them more than others, even as most White people have not asked for that help.

Just because you aren't to blame for the way the system works doesn't mean that you don't unfairly benefit from it. So it ain't enough to say, "well, I worked hard for what I have." White language supremacy ain't about how hard you worked to get what you got. It's about the fact that your hard work doesn't equate to the same rewards as others, that White people's hard work is worth more than people of color's, and that this fact is set up in our systems of rewards and punishments.

Meanwhile, the same systems make it more difficult for people of color to receive the same kinds of rewards with the same kinds of efforts and work. And these systems are overlapping. You cannot just get rid of one White supremacist set of structures and think you've solved the problem of White supremacy. These are the conditions of life in the US, and they are so ubiquitous, so normal, so dispassionate in the way they function, we often don't notice how racist they are.

The conditions of White language supremacy are those in which the environment is set up so that rewards move mostly in one direction-that is, they are given to particular people with particular linguistic and bodily dispositions or habits. These language habits historically have come from a White racial formation. ${ }^{8}$ The assumptions about these language habits are that they are the best, clearest, and most effective ways to communicate. The rewards, opportunities, and privileges that these habits give people are not usually described or identified as racialized in nature, but because of the racialized outcomes that they produce (like fewer African American and Latine9 in certain key professions), they really

8 I use "racial formation" as well as "racial group," but racial formation preserves the dynamic and evolving nature of any group of people defined by a socially changing construct like race-race is "forming" always. This means that a racial formation such as a White racial formation is different today in New York than it was say in 1900 in the same place, or different from a White racial formation in London, England. What it means to be White is not static but changes depending on place and time. I take the term "racial formation" from Michael Omi and Howard Winant, Racial Formation in the United States, 3rd ed. (New York: Routledge, 2015), 109.

9 The terms Latino, Latina, Latinx, and Latine, which are various ways that many use to refer to those who come from Central and South America, are complicated and political. There has been much debate about the use of these terms. Latinx has been used as a gender inclusive term, but the " $\mathrm{x}$ " ending is not a Spanish language ending, and many consider it an Anglicized version of the root word, which has masculine (o) and feminine (a) ends depending on the 
are racist in practice, or de facto.

For instance, we say we just want our lawyers or nurses to speak clearly and effectively in order to do their jobs well, but what we mean by clear and effective speech is language that matches a dominant form of English that excludes Black English and other English varieties. The assumption is that other forms of English are less communicative, less effective, less professional, or less able to do the jobs of lawyering or nursing. ${ }^{10}$ This dominant standard of English comes from a group of White, middle and upper class, monolingual men who speak English and often come from New England or the East Coast.

While we can say that African Americans are not inherently born predisposed to speaking Black English, many do, more do than White people, relative to each group's total numbers. There are lots of structural reasons for this linguistic phenomenon in society, which have to do with where many African Americans have lived or have been forced to live, where they go to school, and where and who they commune with in churches, schools, and neighborhoods.

The same historical and social dynamics that create the conditions for many Black Americans to use Black English also create conditions for many White

reference. The " $\mathrm{e}$ " ending, which is a gender neutral ending in Spanish, is also used for a gender neutral reference; however, some point out that the " $\mathrm{e}$ " ending on "Latino" is illegitimate, since it has not been there historically. I am unsure. Language changes all the time. My mentor, Victor Villanueva, who is Puerto Rican and speaks English and Spanish, prefers "Latine" to refer to those from Central and South America, so I will use that term in this book for the gender inclusive term, realizing that this decision may be contested. For some discussion on these terms, see Ecleen Luzmila Caraballo, "This Comic Breaks Down Latinx vs. Latine for Those Who Want to Be Gender-Inclusive," Remezcla, October 24, 2019, https://remezcla.com/culture/ latinx-latine-comic/; Raquel Reichard, "Latino/a vs. Latinx vs. Latine: Which Word Best Solves Spanish's Gender Problem?” Latina, March 30 2017, http://latina-1051845746.us-east-1.elb. amazonaws.com/lifestyle/our-issues/latinoa-latinx-latine-solving-spanish-gender-problem. And to see a comic strip that breaks down the term nicely, see Terry Blas, "'Latinx' is Growing in Popularity. I Made a Comic to Help You Understand Why," The Highlight by VOX, last updated October 23, 2019, https:/www.vox.com/the-highlight/2019/10/15/20914347/latin-latina-latino-latinx-means.

10 While she doesn't explain the structural reasons for the phenomenon, Yolanda Young provides statistics from the American Bar Association on the number of Black and White lawyers, clerks, and judges in the U.S. She explains, "According to the American Bar Association, 88\% of all lawyers are White and only $4.8 \%$ are Black, so for each of the 60,864 Black lawyers, there are 686 Black citizens needing assistance (compared with only 282 White citizens for each of the $1,117,118$ White lawyers)." In actuality, the disparity is of course much greater because African Americans are disproportionately entangled in the criminal justice system-one in 15 Black men is incarcerated, compared to one in 106 White men. See Yolanda Young, "Why the U.S. Needs Black Lawyers Even More Than It Needs Black Police," Guardian, May 11, 2015, https://www. theguardian.com/world/2015/may/11/why-the-us-needs-black-lawyers. 
Americans to use versions of English that share more language conventions with the dominant Standardized English. ${ }^{11}$ The result is unsurprising: African Americans lose opportunities. But they do so not because they are Black, but because they use Black Englishes. This really means statistically that if you are Black, you ain't likely to be a lawyer or doctor. And as I'll show in my story, your English is you, and you are your English. Making decisions based on the kind of English a person uses is making decisions based on race.

Language standards are a way to be White supremacist without being White supremacist or using White supremacist language. In 1981, Martin Barker, a professor of media and cultural studies at the University of West England (and later at Aberystwyth University), identified a similar phenomenon in public children's comics and literature in the United Kingdom under the rule of Margaret Thatcher. Barker coined the term "new racism" that identified the way these language strategies maintained the same old racist policies, ideas, and outcomes. ${ }^{12}$

Similarly, Eduardo Bonilla-Silva's important sociological studies show how US students and others can be racist without being racist. ${ }^{13}$ We can have good intentions, be good people, demand "clear and logical" writing from students in schools, yet through those standards we end up promoting White language supremacy because those standards and expectations come historically from a White racial formation in the Western world. I'll say much more about this in the rest of this book. When such standards are used to decide grades, opportunities, and preferred methods of communication for everyone, they privilege White people and disadvantage people of color and poor people. It's White language supremacy without White supremacists.

11 For a definitive study of Black English, see Geneva Smitherman, Talkin and Testifying: The Language of Black America (Detroit: Wayne State University Press, 1977). For discussions on the relationship between race and language attitudes, see H. Samy Alim, John R. Rickford, and Arnetha Ball, eds., Raciolinguistics: How Language Shapes Our Ideas About Race (New York: Oxford University Press, 2016).

12 Martin Barker, The New Racism: Conservatives and the Ideology of the Tribe (London: Junction Books 1981).

13 See Eduardo Bonilla-Silva, "Rethinking Racism: Toward a Structural Interpretation," American Sociological Review 62, no. 3 (1997): 465-480, https://doi.org/10.2307/2657316; Eduardo Bonilla-Silva, White Supremacy and Racism in the Post-Civil Rights Era (Boulder, CO: Lynne Rienner, 2001); Eduardo Bonilla-Silva, “'New Racism,' Color-Blind Racism, and the Future of Whiteness in America," in White Out: The Continuing Significance of Racism, ed. A. W. Doane and E. Bonilla-Silva (New York: Routledge, 2003), 271-284; Eduardo Bonilla-Silva, Racism Without Racists: Color-Blind Racism and the Persistence of Racial Inequality in the United States (Lanham, MD: Rowman and Littlefield, 2003). 


\section{THE POLITICS OF LANGUAGE}

In this book, when I speak of White language supremacy, I'm also talking about the politics of English languages. What do I mean by "politics"? I'm not referencing political parties or agendas in the typical sense of the word, "politics." That is, I'm not talking about whether someone is a Democrat or a Republican. It isn't those kinds of politics I am linking to standards and language usage. I'm referring to power relations in social and institutional settings, like schools, offices, churches, and public settings. And these power relations are always uneven or unequal. Some people have more power to do and say things than others in particular contexts. Some are more influential than others. Part of this phenomenon is due to the ways our Englishes are unequal.

And so in each setting, some ideas and words are more influential, attractive, and compelling than others. Conversely, there are other words and ideas that are less attractive, negative, or repellent than some. In short, politics means power relationships between people and between various language habits. So when I say that our use of language standards is political, I mean that not everyone gets to make judgements and decisions about language usage or standards that count and that not all words and ideas are considered equally, even when they should be. This means that not everyone gets to be heard or read as authoritative or compelling or persuasive for all kinds of reasons that have little to do with what they are saying and a lot more do with where they come from or who they are understood to be.

Let me give you an example that you likely have a lot of experience with. In classrooms, the teacher has more power to administer rewards and punishments, to make those in the class do things. Students usually have very little power to do this. We generally know why these politics work this way in schools. Teachers are trained in the subjects they teach and hired by schools to teach, thus their expertise is validated in many ways that we do not question. People with college degrees have knowledge and experiences that give them expertise in areas like teaching writing or history. They are granted more power to control things in classrooms because of their expertise.

Often, titles and positions-like teacher or professor, doctor or lawyer-as well as the money (salary) that goes along with such titles confirm to us that those people know things, that an institution or company has confirmed their knowledge and given them power to exercise. They are qualified to do their job and control things. They are often seen as knowledgeable and trustworthy in their areas of work and expertise. The teacher or doctor couldn't be hired to do their job otherwise, right? There are vetting processes that are competitive. So the most qualified end up with jobs, right? 
But we can only accept the expertise of the teacher on these grounds if we accept the overlapping systems and institutions of education, commerce, training, and hiring in schools that create that expertise and in turn create the politics of the classroom. So the sources of power relations among people and their words are structural. Systems create power. And as DiAngelo's list of White dominated leaders and influencers shows, these systems currently reproduce authorities and experts who come from the same places as each other, White places. So really, our current systems create White power.

These same politics work in every language situation in our lives. Even sitting around our dinner table talking to our family members is created by conditions that affect the language we use and how it is heard and judged by those around us. I'm not suggesting that we question all authority, or that everyone with power should not have it. I'm saying that there is always a politics that constructs what we understand, how we understand it, who gets to make the rules and decisions, and what language and ideas end up being judged as acceptable and most compelling.

So, when we notice that an idea is very persuasive to many people, like the idea that "in the US, hard work always pays off," then we might ask: What political conditions help give that idea power? What conditions or systems make it compelling and persuasive in the present situation? We do not control a lot of the conditions we find ourselves in each day. For instance, none of us control the fact that in the US, most consider the language of business, education, commerce, politics, and everyday social life to be a particular kind of English.

We don't control the history of how that English has been used in any of those past settings in the US. We don't control who has been in control in those settings or what their biases and experiences with language, particular ideas, and people were. We just inherit these conditions. And these conditions shape further conditions, such as when we find ourselves sitting in a classroom or living room entertaining the idea that "in the US, hard work always pays off," or "my doctor or nurse should speak 'proper English."”

But there are more overlapping factors that contribute to our language conditions and the politics inherent in them. Our own histories, biases, experiences, and idiosyncrasies also form language conditions. For example, we don't choose the particular brand of English, if that's your first language, that we speak and use. It is an inheritance, not a choice. It is a gift from our elders who nurtured us as children and adolescents. It evolves with those friends and others with whom we commune on a daily basis, a product of countless tiny decisions made each day in our lives, until what we say and how we say it all just seems natural to us.

Our own version of English is also a product of an incredible string of lucky circumstances that brought each of us to where we are today, regardless of who 
we are, what kind of English we speak, and what our pasts are. No one chooses where their family is from. And geography plays an important part in how languages are formed and evolve. That's why people in Atlanta speak and use English differently than those in Chicago, or New York, or Los Angeles.

But some locations, and the people who operate in them, are understood as more important than other locations and people. That is, New York is the center of publishing in the US. Los Angeles is the center of the entertainment industry. And the languages used by people in those places have dictated what is standard in them. If we are not thinking slowly enough, we may falsely assume that the languages of those two places are universal, that people in rural Kentucky should speak just like those in Los Angeles, California.

Politics, or the relations of power, is always a part of how we use language, how our languaging is judged, and how we judge others. When we pan back to see a larger swath of history, we find out that it's not hard to see who has had politics on their side. White people have controlled all of the systems and structures, the standards and practices, that create the version of English that has come to be acceptable and most valued in all areas of life.

In order to maintain White language supremacy, or deny that it exists and assume that language is neutral and universal, there are things about language that have to be ignored. The first is that language itself is political. Ignore this fact and it's easier to blame people for the language they speak, call them ignorant, lazy, or dumb, and deny them opportunities in society, all the while saying it's all fair because it's all neutral. We are just trying to put the most qualified and smartest people in the right places, and we are using language, not our racial biases and prejudices, to determine who gets into those places. If you do not ignore the politics of language, you cannot come to this conclusion. But remember, White language supremacy is a condition that has overlapping and redundant structures. There are lots of other things you have to ignore as well, which my story in this book will try to show you.

\section{SIX HABITS OF WHITE LANGUAGE AND JUDGEMENT}

Finally, in this book, I'll reference what I call habits of White language and judgement, or habits of White language, HOWL for short. These are the language habits usually assumed or promoted as universally appropriate, correct, or best in writing and speaking by those with power to do so. Historically, these habits of language have come out of elite White racial groups in Western, monolingual, English speaking societies, as I'll illustrate in chapters 2, 3, 4, and 5 in various ways. There is nothing inherently racist about these habits of language. However, when they are used as universal standards for communication, used to bestow 
opportunities and privileges to people, then they become racist and produce White language supremacy.

Using the research on Whiteness, I've found at least six habits that often embody Whiteness as a privileged language position. These six habits of White language and judgement don't always exist at the same time in the same text or language expression, but the first one listed is almost always present in White supremacist expressions.

The presence of one habit in a text or judgement doesn't always equate to being White supremacist or producing White supremacy, but it often can. Usually the difference is in what that instance of language or judgement produces in the places it circulates. Is the outcome of the language or judgement a racially unequal or unfair distribution of resources, jobs, grades, etc.? Does it produce a racialized hierarchy in society? If so, then it is White supremacist.

Understanding when White language supremacy is happening not only helps us understand the consequences of a judgement or decision, but how that judgement or decision is made, how the habits are used to explain or think through language and other judgements. What ideas, values, competencies, or conditions of individuals or groups are assumed to be universal or accessible to all? Claims of universal fairness often fall into this category. They usually sound like: "I treat everyone the same," or "I try to be fair by giving everyone the same opportunity to get X or to do Y." But we are all not the same, nor do we come from the same conditions. We all don't get to run the same race, with the same training, or the same equipment. We don't use the same Englishes, not exactly. And these differences are patterned in groups, because our society has been racially and economically segregated into groups. While he does not frame White language and judgement as habits, nor use such terms, Ibram X. Kendi, in Stamped From the Beginning, offers a history of these habits in the racist ideas voiced by influential thinkers, religious leaders, and political figures such as Cotton Mather, Thomas Jefferson, Samuel Sewall, and John Saffin. ${ }^{14}$

Equally important to remember is that the intentions of writers, speakers, or institutions do not matter when determining whether something is White supremacist or racist. Because White language supremacy is a systemic and structural set of conditions that have been created historically, it is not an ethical blemish to say that someone is reproducing White language supremacy. When we determine that our judgements or decisions reproduce White language supremacy, we are not making any claims about the morality or goodness of peo-

14 The first twelve chapters in Ibram X. Kendi, Stamped From The Beginning: The Definitive History of Racist Ideas in America (New York: Nation Books, 2016) are particularly illustrative of how all six habits of White language and judgement were established as common sense, neutral language practices, and compelling ways to use the English language. 
ple or institutions. We are identifying the way systems work and their biases in order to take responsibility and move forward, change, and make things better tomorrow.

Taking responsibility is an ethical imperative, something we do because we wish to act compassionately. Being to blame for perpetrating some injustice upon others is a judgement that is often understood as a moral failing. Taking responsibility for our world is what we do because it is our world, and the vast majority of us want to make it better for ourselves, for others, and those who come after us.

Here are the six habits of White language and judgement, or HOWL, that I'll reference throughout this book. ${ }^{15}$

- Unseen, Naturalized Orientation to the World-This is an orientation, a starting point, of one's body in time and space that makes certain habits, capacities, practices, languages, and ideas reachable. It assumes, or takes as universal, its own proximities or capabilities to act and do things that are inherited through one's shared space. It can be understood as an "oxymoronic haunting," 16 leaving concepts and ideas unsaid or unstated for those in the classroom or other place to fill in. It is often stated or understood as "clear only if know" (or COIK). ${ }^{17}$ The authority figure knows precisely and assumes everyone else does too. When a teacher, writer, or authority embodies this habit, they often do not realize it, assuming that everyone has access to the same languages, concepts, practices, capacities, histories, and logics that

15 Previous versions of HOWL are in: Asao B. Inoue, Labor-Based Grading Contracts: Building Equity and Inclusion in the Compassionate Writing Classroom (Fort Collins, CO: WAC Clearinghouse and University Press of Colorado, 2019), 27, 278-279, https://doi.org/10.37514/PER-B.2019.0216.0; Asao B. Inoue, "Classroom Writing Assessment as an Antiracist Practice: Confronting White Supremacy in the Judgments of Language," Pedagogy 19, no. 3, (October 2019): 373-404, https://doi. org/10.1215/15314200-7615366.

16 See, Tammie M. Kennedy, Joyce Irene Middleton, and Krista Ratcliffe, eds., Rhetorics of Whiteness: Postracial Hauntings in Popular Culture, Social Media, and Education (Carbondale, IL: Southern Illinois University Press, 2017), 4-7.

17 A COIK orientation often operates from ambiguous or floating key terms and ideas. For example, in the statement, "Americans are a free people," the term "free" floats. It can mean a number of things depending on who you are. COIK orientations leave key ideas or terms floating but assume a universal understanding of them. To read about "floating signifiers," see, Claude Lévi-Strauss, Introduction to the Work of Marcel Mauss, trans. Felicity Baker (London: Routledge and Kegan Paul, 1987), 63-64; "Floating Signifier," Beautiful Trouble, ed. Andrew Boyd and Dave Oswald Mitchell (OR Books, 2012; repr. https://beautifultrouble.org/theory/ floating-signifier/). 
they do. In this way, the classroom, or an ideal paper, or an expected language performance becomes an extension of the White body, its habits, and its languaging in such a way that it is hard to distinguish it as an orientation, body, or space in the classroom or other place. It's just, for instance, a standard that is both associated with but understood as separate from Whiteness and White bodies. ${ }^{18}$

- Hyperindividualism - This is a stance or judgement that primarily values self-determination and autonomy as most important or most valued. It often centers or assumes values of the self as an individual, self-reliance, self-sufficiency, and self-control, which tend to also support logics like "survival of the fitness," "free and open markets," and competition as proving grounds for discovering the best or what is most ideal. It can appeal to ideals of universal truths and knowledge that come from inside the individual. This personal insight is often understood as universal insight. The logic is that everyone is the same because we are all the same inside, while also holding on to the importance and primacy of the individual, even the individual as the exception. Individual rights and privacy are often most important and construct the common good or what is best in society or groups. Thus the best outcome of a class or an assignment or activity is something personal-a personal grade, a personal insight or learning, a better draft-but not a benefit to the community, group, or class as a whole (that is an indirect, secondary benefit). In this way, the point of society, school, the classroom and its activities is to serve the interests and growth of the individual, not the community. ${ }^{19}$

- Stance of Neutrality, Objectivity, and Apoliticality - This is an orientation that assumes or invokes a voice (and body), or its own discourse, as neutral and apolitical, as non-racial and non-gendered. This is often voiced in the style of a "god-trick," which is a universal vantage or viewpoint by which to know something else in a nonpo-

18 I draw on Sara Ahmed, "A Phenomenology of Whiteness," Feminist Theory 8, no. 2, (2007): 149-168, https://doi.org/10.1177/1464700107078139; Robin DiAngelo, White Fragility.

19 For this habit, I draw on, Richard Brookhiser, "The Way of the WASP," in Critical White Studies: Looking Behind the Mirror, ed. Richard Delgado and Jean Stefancic (Philadelphia: Temple University Press, 1997), 16-23; Catherine Myser, "Differences from Somewhere: The Normativity of Whiteness in Bioethics in the United States," The American Journal of Bioethics 3, no. 2 (2003): 1-11, https://doi.org/10.1162/152651603766436072; David McGill, and John K. Pearce, "British Families," in Ethnicity and Family Therapy, ed. Monica McGoldrick, Joe Giordano, and Nydia Garcia-Preto (New York: Guildford Press, 1982), 457-479; DiAngelo, White Fragility. 
litical or purely objective way. It is a view that is outside the person speaking or expressing the ideas. Often, this stance also manifests as an urge toward universalism, or a one-size-fits-all mentality. Facts are just facts, not created or manufactured by people or processes or language. Contexts are deemphasized or ignored. Ideas, from this orientation, can be outside of the people who articulate them. A rubric or set of language expectations in a classroom, for example is assumed to be apolitical, outside of the gendered and racialized people who made it (and the racialized and classed groups and places those people come from). ${ }^{20}$

- Individualized, Rational, Controlled Self-This is a stance or orientation in which the person is conceived of as an individual who is primarily rational, self-conscious, self-controlled, and self-determined. One's own conscience guides the individual. Sight (ocularity) is the primary way to identify the truth or to understand something (i.e. seeing is proof; seeing is understanding; seeing is believing). This makes social and cultural factors into external constraints on the individual, which must always be ignored or overcome. Meaningful issues and questions always lie within the rational self. Individuals have problems, making solutions individually-based. Thus, both success and failure are individual in nature. In a classroom or other space, failure is individual and often seen as weakness or confirmation of inadequacy or a lack of control. Personal control of one's self, body, and voice are important because it shows that the individual is in control and rational. Often part of self-control is the ability to continually work and stay busy or be industrious and productive in approved (or predefined) ways within the system or classroom. ${ }^{21}$

- Rule-Governed, Contractual Relationships-This habit focuses on the individual in a contractual relationship with other individuals,

20 I draw on Toni Morrison, Playing in the Dark: Whiteness and the Literary Imagination (Cambridge, MA: Harvard University Press, 1992); bell hooks, "Representing Whiteness in the Black Imagination," in Displacing Whiteness: Essays in Social and Cultural Criticism, ed. Ruth Frankenberg (Durham, NC: Duke University Press, 1997), 338-346; Timothy Barnett, "Reading 'Whiteness' in English Studies," College English 63, no. 1 (2000): 9-37, https://doi. org/10.2307/379029; Marilyn Frye, "White Woman Feminist," in Willful Virgin: Essays on Feminism 1976-1992 (Freedom, CA: The Crossing Press, 1992), 147-169; Donna Haraway, "Situated Knowledges: The Science Question in Feminism and the Privilege of Partial Perspective," Feminist Studies 14, no. 3 (Fall 1988): 575-599, https://doi.org/10.2307/3178066 ; Myser, "Differences from Somewhere."

21 I draw on Brookhiser, "The Way"; Barnett, "Reading "Whiteness"”; Haraway, "Situated"; Myser, "Differences from Somewhere"; DiAngelo, White Fragility. 
either formally or tacitly, that tends to be understood as benefiting the individuals in the contract, not the whole community or group. This habit can be seen in syllabi as one kind of assumed social and educational contract that is dictated by those in power (teachers and schools) for the assumed benefit of individual students. Additionally, a focus on or value in "informed consent" (often confirmed in writing) is important. Ideal relationships are understood to negotiate individual needs or individual rights, which are apolitical and universal. Meanwhile, socially-oriented values and questions are less important and often understood as inherently political (and therefore bad or less preferable). There is an importance attached to laws, rules, fairness as sameness and consistency, so fair classrooms and other spaces are understood to be ones that treat every individual exactly the same regardless of who they are, how they got there, where they came from, or what their individual circumstances are. Very little, if any, emphasis is given to interconnectedness with others, relatedness, or feelings in such classrooms or in other arrangements, activities, and relationships. Individuals keep difficulties and problems to themselves because the important thing is the contractual agreement made. ${ }^{22}$

- Clarity, Order, and Control-This habit focuses on reason, order, and control as guiding principles for understanding and judgement as well as for documents and instances of languaging. Thinking and anti-sensuality are primary and opposed to feelings and emotions. Logical insight, the rational, order, and objectivity are valued most and opposed to the subjective and emotional. Rigor, order, clarity, and consistency are all valued highly and tightly prescribed, often using a dominant, standardized English language that comes from a White, middle-toupper-class group of people. Thinking, rationality, and knowledge are apolitical, unraced, and can be objectively displayed. Words, ideas, and language itself are disembodied, or extracted, from the people and their material and emotional contexts from which the language was created or exists. Language can be separated from those who offer it. There is limited value given to sensual experiences, considerations of the body, sensations, and feelings. A belief in scientific method, discovery, and knowledge is often primary, as is a reliance on deductive logics. Other logics that often distinguish this habit in classrooms and

22 I draw on David Roediger, The Wages of Whiteness: Race and the Making of the American Working Class, rev. ed. (London: Verso, 1999); George Lipsitz, The Possessive Investment in Whiteness: How White People Profit from Identity Politics (Philadelphia: Temple University Press, 1998); Myser, "Differences from Somewhere"; Frye, "White Woman Feminist." 
Chapter 0

other spaces are those that emphasize usefulness or unity and pragmatic outcomes, all of which are predefined for individuals by authorities, such as a teacher. ${ }^{23}$

23 I draw on hooks, "Representing Whiteness"; Brookhiser, "The Way"; Myser, "Differences from Somewhere"; Barnett, "Reading "Whiteness." 


\section{CHAPTER 1.}

\section{LITERACY IS (NOT) LIBERATION}

When I was seven years old, I won my school's reading contest by reading the most books in the second grade. I set goals each week, read every night after dinner until I went to bed. For each book, I wrote a one or two sentence summary on a special slip of paper that my mom and I would sign, proving I'd read each book. I'd return to class each day with several of these slips in hand, giving them to my teacher, Mrs. Whitmore, a tall, husky, White lady with a gruff voice that softened at the corners of some words, especially when she asked questions.

Every book I read gave me more confidence to read the next one, to choose harder and longer ones. Engaging so intensely on this reading contest was a way I could escape the poverty we lived in. It came at a time when I was beginning to understand who I was, what was missing in my life, and what was present. It was also a moment when I realized that I loved words. Learning so-called "Standard English," reading and writing it well, symbolized to me what it meant to be successful, to be a man, and to be free from the oppressive conditions around me.

I don't want you to get the wrong idea. My growing up had lots of love and happiness in it, but there was also other not so great stuff. And that stuff got mixed up with my coming to my own literacy. It got mixed up with my understanding of myself as a boy of color in schools and public spaces. You see, during my elementary years, we were very poor, lived in North Las Vegas (North LV) in government subsidized apartments on Statz Street. Too often, there was more month than money, more days left until the first than we had boxes of macaroni and cheese or Top Ramen in the cupboard. And forget meat or milk, those were luxuries, like little food vacations — only the rich could afford those things.

Too often, I did not get new clothes or shoes for school. One year, I had to wear the previous year's shoes. My shoes had big holes right through the bottoms of them. They were brown sneakers with three yellow zig zag lines on the sides. They were an off-brand, Trax. I could feel the ground when I walked, the hot Vegas asphalt nipping at the balls of my feet with each step. I won't say that I was blissfully unaware of our circumstances, that the love in our home made up for the lack of most everything else. That would be a lie. I knew I was poor. I could feel it in our circumstances and on the bottoms of my feet.

At the time, North LV was primarily a Black city, a poor ghetto. It has changed since because of population increases in Las Vegas during the 1980s and ' 90 s, but in the '70s, it was considered a poor and run down city. Of course, 
now I see where this language comes from. It is racialized, or rather it is the way racism is voiced today. "Run down" cities are always pseudonyms for race, and serve as warnings to White folks and those who can heed the warning.

In the US, most people avoid speaking of race, or labeling people or ideas or language as racial, in polite company. The habits of the dominant group in the US today, their standards by which we all get judged in and out of school, dictate that race not be mentioned explicitly in conversations. The Whiteness hides. If you have to, you say it in hushed tones and whispers. But to say it out loud, explicitly, that would be rude, and even racist itself, or so goes the logic. But race is threaded into all of our material conditions. We don't have to talk about it for it to still be integral to all that we do and say.

Such terms as "run down" are facially non-racial terms for where Black or Latine people live. It's the same as saying, "the bad part of town." Why is that area less desirable, and to whom? Of whose desire are we speaking? During the 1970s and '80s, the intersections of race, economics, and class coalesced in North LV around a mostly Black racial formation. And part of what made that Black racial formation and the negative image of the city was the redlining practices of banks in the 1950s and '60s, which allowed banks to refuse loans in the area. Banks drew red lines around areas on maps where people of color lived, and called those areas decrepit or run down, which gave them reason not to loan money to people or build in those areas. ${ }^{1}$

This meant that over time, no new development, housing or commercial building occurred. This meant no jobs. No money circulating in that area. This meant that things got worn out. People had to figure out how to make a living or survive or escape the rundown-ness of things. Some chose drugs or gangs or prostitution, and some like me, chose reading. But all of these options were the ways of escape that were available to each of us. Language happened to be available to me more so than most of my Black friends and neighbors. And yet, I'm positive I was only one or two decisions away from prison, and not a professor of writing at a big university.

This racist history of a generation before me created the North LV I grew up in. It kept opportunity out and Black and Brown bodies in. It meant that if you wanted to work, you had to have a way to get out of North LV and to the place where the job was, either with a car, which meant lots of gas, or by bus, which meant lots

1 To read about some of the redlining practices in North Las Vegas, see Jenna Kohler, "The Other Vegas," Las Vegas Sun, May 15, 2008, https://lasvegassun.com/news/2008/may/15/ other-las-vegas/; or to see interactive maps of the US that show the redlining practices in many locations, see "Mapping Inequality: Redlining in New Deal America," American Panorama, University of Richmond Digital Scholarship Lab, accessed February 25, 2021, https://dsl.richmond. edu/panorama/redlining/\#loc=4/39.854/-101.679. 
of extra travel time. Bottom line, the history of North LV made conditions that kept everyone poor with little ability to create equity in homes or wealth.

Consequently, it is no easy feat to leave Statz Street because you also have to get out of debt and accumulate some wealth. My mom did it by working three jobs and getting help from her sister's husband, my uncle Bill, a university professor in another state who married my mom's sister. He was a working-class White man from Iowa who became an internationally known microbiologist with hundreds of patents under his name, mostly for processes that made cheese. And even with his help, our leaving depended on my mom finding another roommate to live with us and share the rent. So while we were poor, we had some privilege, some help, some friends, and some way out. We had some chances to get out and up. We took them.

At the time on Statz, our poverty affected the way I heard words, too. This is the time I can remember my mom talking about "making ends meet," scraping by until the next payday. But what I heard was "making ends-meat." I thought the expression was one that used the metaphor of food, of preparing the ends of meat, the leftover parts, perhaps the grizzly sections that might get thrown away in good times, but one could eat them in lean times to get by for just a bit longer.

Today, I still visualize in my head making ends-meat, because making ends meet doesn't make any sense to me. It just sounds like circular logic. What ends meet and where? Why are they meeting? How is connecting two ends of something a metaphor for getting by in tough times when you don't have much food in the cupboard? How does that feed a hungry belly? The contexts for getting by in my life's formative years were driven by hunger for anything to eat as well as a hunger for words. But in those early years, food was always on my mind. We were so poor that we didn't have much of it, and I was always hungry. So it makes sense that I'd hear a food metaphor in these daily conversations around survival.

So that second grade reading contest was important to me, even though I didn't really understand why at the time. I'm not sure why I wanted to win so badly; maybe it was because of the poverty; maybe I wanted to have something that others didn't. Maybe I thought it was a way to get some favor from a teacher who seemed to have none for me. It was a time when I was just discovering my love for words and language. It was an escape.

Words seemed like something I could control. Maybe this contest cultivated my love for language; maybe that love was already there, inevitable. I don't know. What I do know is that I thought about that contest every day for most of my second grade year. I hate to think what would have happened had I lost. But I didn't. Losing at words would not be my destiny, not then nor later, at least not when it really counted. 
I still remember the ceremony. An administrator, perhaps the vice principal, came into our class, called me up to the front of the room, and presented me with two trophies, one for the most books read in our class and one for the most in all of the second grade classes. I was very proud, but the whole affair was tainted. After I got the awards, I was escorted, as was the daily custom, back to my remedial reading classroom for reading lessons. I was a remedial reading student through most of my elementary and junior high years.

It didn't matter how many books I'd read or what reading contest I'd won. It didn't matter that I loved reading from that point on, that I spent much of my spare time reading at home. I always had a stack of books checked out from the library. It didn't matter that my brother and I wrote stories to each other on my mom's Montgomery Ward Signature typewriter, just for fun. It didn't matter that in the cafeteria and on the block no one would verbally spar with either of us. We were just too good at words, too good at put-downs, at cappin, at talkin bout "ya momma." We could quickly undo your logic, tangle and reshape your own words, and use them against you — and strangle you with them.

Words were weapons and medicine that made my life better, that made me a king outside of the classroom and protected me or soothed my wounds in quiet moments. And yet in the classroom, my grades, while not bad, were not great either. I often teetered on the brink of failure in those early years of elementary school. And to make matters worse, during this period and throughout the rest of my schooling, I was constantly confronted with my racial identity. I would learn later in college that English language literacy and racial identity are closely related, wedded, in the US. ${ }^{2}$

Much later in my life, in graduate school, I'd learn about educators and language scholars who talked about how we make meaning of the words and other symbols in our lives from the material of our lives, from what we already know, experience, and read. We understand, hear, and see what we are prepared to understand, hear, and see. We recognize the things we have names for.

We see a dog because we have a name for such a creature, and that name helps us make sense of how to relate to this creature. Is it a pet or a guard dog? We see round objects because we have a concept and name for such an occurrence, an

2 There are lots of resources one can read to understand the connections between race and English language literacy. See, for example, H. Samy Alim, John R. Rickford, and Arnetha F. Ball, Raciolinguistics; Vershawn A. Young, Your Average Nigga: Performing Race, Literacy, and Masculinity (Detroit: Wayne State University Press, 2007); Suhanthie Motha, Race, Empire, and English Language Teaching: Creating Responsible and Ethical Anti-Racist Practice (New York: Teachers College Press, 2014); Morris Young, Minor Re/Visions: Asian American Literacy Narratives as a Rhetoric of Citizenship (Carbondale: Southern Illinois University Press, 2004); Victor Villanueva, Bootstraps: From An American Academic of Color (Urbana: NCTE, 1993). 
object without straight or flat sides, no angles. These words help us make sense of what is otherwise meaningless and reveal patterns in the chaos of life.

The words we have also are keys to our liberation from oppressive systems. And this is what I subconsciously grabbed onto as a young reader of English. There are many examples today of the liberatory value of literacy and of those who have proclaimed such ideas: Henry David Thoreau, Frederick Douglass, Malcolm X, Margaret Fuller, Malala Yousafzai, bell hooks, Gloria Anzaldúa, Maya Angelou. Another was a mid-twentieth century Brazilian educator named Paulo Freire, who described the process of acquiring written literacy as a liberatory process, one that gives people power over their lives, power over the conditions that oppress them. Literacy gives people control of their lives' conditions, in part because it allows us to name them, abstract them, restructure them. Freire explains the connection between the written word and the material world: "Reading the world precedes reading the word, and the subsequent reading of the word cannot dispense with continually reading the world. Language and reality are dynamically intertwined. The understanding attained by critical reading of a text implies perceiving the relationship between text and context." ${ }^{3}$

Key to Freire's ideas about literacy and its attainment is the term "critical" in "critical reading." He means something very particular. It's not a deposit or "banking model" of literacy where the teacher deposits learning, ideas, or words into the student's brain, then that student uses that understanding to decipher text. This would ignore the fact that we have histories with words, objects, places, people, and ideas. Words have relations to us. They affect us, our thinking, and our views of the world and those in it. And these relations and consequences are different depending on who you are and where and how you live. It assumes people don't have prior or ongoing relations to the world and words. In fact, it ignores these relations completely.

To Freire, critical reading, on the other hand, is a process of what he calls "problematizing" one's own material and existential situation. ${ }^{4}$ If we are being critical in our reading practices, Freire says, it should lead to our asking questions about our reality and about how it makes us and we make it. Our reading of words leads to rereading the world, and our experience of the world should help

3 Paulo Freire, "The Importance of the Act of Reading," trans. Loretta Slover, The Journal of Education 165, no. 1, (Winter 1983): 5-11, https://doi.org/10.1177/002205748316500103. To read more about Freire's position on literacy, see Paolo Freire and Donald P. Macedo, Literacy: Reading the Word \& the World (South Hadley, MA: Bergin \& Garvey Publishers, 1987).

4 In case it helps, "existential" simply refers to the nature of one's existence. If our material lives might be questioned by asking, "what makes up my existence," then to question our existential lives, we might ask, "how do my material conditions make up my existence." 
us read words. The kinds of questions Freire urges are ones that help us pose problems about our world and the degree to which we control it and it controls us.

Critical reading, then, is a practice of reading words and pausing to pose questions about our relation to our material situation, our reality in those words. ${ }^{5}$ Freire implies that the words we use can tell us a lot about who we are and where we come from. Critical reading urges us to do more reading, find out more information about our world and thus ourselves.

My hearing "ends-meat" was about more than a boy being hungry all the time, hearing what he needed to hear in words. The words that were important to me at that moment of my life when I heard my mom talk about the rent and what was left in the cupboard were usually about basic needs: food, shelter. They were never abstract. There were no metaphorical ends of something that needed meeting. The end was always food, at least in my mind. And I can see now that my rendition of that euphemism was not a mistake. I made the meaning I could, and those words made me as much as I made them. It was me languaging through my material conditions. Freire helps me see that my literacy is both my liberation and my oppression and many other things.

We live on Statz in a small, two-bedroom, white brick apartment. My mom sits at our small kitchen table, a wobbly, spindle-legged thing with a plant at its center. She always loved plants. She's got a pen in her right hand, even though she is left-handed. Her older sister, my aunt, trained her to write with her right hand when she was little, telling her that people don't write with their left hands, not realizing that one can write with either hand. So my mom is ambidextrous.

I walk up to the table and crane up to see what she's writing. It's interesting to me. There are papers and envelopes in neat piles. Her checkbook lies open in front of her. She has a worried look on her face, like she's trying to put together a puzzle without some of the pieces. She cocks her head one way, then another, trying to find another perspective on this problem. She mouths something. She's talking to herself silently. I'm watching her and hungry since it's close to dinner time, but I'm curious when I see the pen and papers.

"What's that?" I point at her familiar green steno pad. The pad has a hard, cardboard back and front, with a wire spiral binding at the top of the pages, allowing it to open like a sandwich board. Mom always had a number of these all over the place. Open any drawer in the apartment, and there were likely several of them in there. Even today she keeps stacks of them. My mom likes to work in

5 To learn more about problematizing and Freire's dialogic teaching methods, see chapter 3 of Paulo Freire, Pedagogy of the Oppressed, 30th anniversary ed. (New York: Continuum, 2000). 
steno pads, saving them as a way to remember things years later.

She told me once that she'll pull one out and reminisce. It's like a history of that year or that time of her life. She dates pages. When one is filled up, she writes the date on the cover. Each pad shows the trials, the worries, the things needing money, things paid for, stuff she was thinking about or working out at that time in her life. Her steno pads are part of her memory and her relations to the world.

"Just trying to pay bills," mom says. I look at her list in her steno pad and I admire her handwriting. My mom's handwriting is delicate, not precise, but her letters have an ornate look to them and are smooth and flowing. I've always loved her handwriting. It seemed to me as a seven year old boy that her handwriting, those hands, could fix anything.

"What's that?" I point to the list she's making in the steno pad. I touch the green paper. I'm curious about the words and numbers. What do they mean? What do they do? The words and numbers seem arcane, magical even. They are conjuring something, I just know it. This is something only moms can do, I think.

"Trying to make ends-meat, sugar plum. We gotta make ends-meat." I'm immediately reminded of my belly. I want dinner, and I think somehow mom is making dinner there at the spindle-legged table with the plant on it, somehow, between her steno pad and check book, somehow the ends of meat are made. 



\section{CHAPTER 2. \\ THE YIN-YANG OF LITERACY}

While I didn't grow up with it formally, the philosophy of Taoism offers me a way to understand my own literacy practices and some of Freire's ideas about critical reading. That is, several of Taoism's core principles describe my own language habits. I don't know how this is, but it is.

Taoism is an ancient Chinese philosophy that explains the order of the universe and everything in it, and it is often encapsulated in the Yin and Yang symbol. Yin and Yang are two entities, male and female energies, that are joined and interconnected. They are interdependent, or mutually dependent on one another, in order to exist. They make each other. Both are necessary for the other's existence. Night needs day and day night. But when does day become night? When is dawn or dusk day or night? The idea is that yin and yang need each other, define each other, thus their borders blur into each other.

Each has the essence of the other in them, hence the circles of the opposite color in both the yin and yang swirls. ${ }^{1}$ We need our material world, our reality, to make meaning of words or the symbolic world, while simultaneously, we need words (the symbolic) to help us make sense of our material world. The two elements and forces coexist and flow back and forth between each other. In some sense, they are each other. In Buddhist traditions, one might say these two energies or realms of experience "inter-are." 2 They are interdependent. Reality is symbolic, and the symbolic is reality. In Christian traditions, a similar concept exists in the idea of consubstantiality. ${ }^{3}$

Cultural psychologists explain that Chinese Taoist dialectic is one that accepts a unity of opposites, accepts that contradictions or tensions in the world

1 To learn more about the roots of Taoism, Confucianism, and Buddhism, see Lao Tzu, Tao Te Ching, trans. David Hinton (Berkeley: Counterpoint, 2015); see also, Robert Wright, Why Buddhism Is True: The Science and Philosophy of Meditation and Enlightenment (New York: Simon and Schuster, 2017).

2 The Vietnamese Buddhist monk and peace activist, Thich Nhat Hanh explains interbeing elegantly in Peace is Every Step: The Path of Mindfulness in Everyday Life (New York: Bantam, 1991), 95-98.

3 In Christian theology, consubstantiality describes the relationship between God (the Father), Jesus Christ (the Son), and the Holy Spirit. They are of the same essence. See Michael Jinkins, Invitation to Theology: A Guide to Study, Conversation \& Practice (Downers Grove, IL: InterVarsity Press, 2001), 117-118. There is also a decent Wikipedia page on the concept; see Wikipedia: The Free Encyclopedia, accessed February 20, 2021, s.v. "consubstantiality," https:// en.wikipedia.org/wiki/Consubstantiality. 
are inherent and are not really contradictions. ${ }^{4}$ So when conflict arises, there is not an inherent need or urge to resolve it, as in Western and Greek traditions. This is the interdependent nature of paradoxical things. What appears as contradictory or in conflict in the world or among ideas and positions is simply the necessary unity of opposites, yin and yang coexisting, commingling.

In Western philosophy, the word "dialectic" comes from ancient Greek ideas about dialogue. To the Greeks, opposing ideas are tested together in order to come to the Truth (capital " $T$ "), or a singular truth, which the ancient Greeks called Episteme. ${ }^{5}$ In Western thinking, a single truth is the goal of a dialogue or dialectic, two or more opposing voices, ideas, or words that produce one conclusion about the question or issue at hand.

This is linear thinking and can be visualized as a straight line with hierarchical points or steps in it from an origin to an end point. Think of it as an outline with topics (e.g. I, II, III, IV) and subtopics (a, b, c, d) under each topic. It's what most people in the West consider "logical," but actually it's just one kind of logic or orientation to the world, one of many. ${ }^{6}$ It's the logic of Plato and later Aristotle that prevailed and was passed on, but there's nothing inherently better or clearer about linear thinking than some other way of thinking or ordering ideas or the world. It's just the kind of thinking that gained dominance for a number of reasons, which is an entirely different book. ${ }^{7}$

$4 \quad$ Kaiping Peng, Julie Spencer-Rodgers, and Zhong Nian, "Naive Dialecticism and The Tao of Chinese Thought," in Indigenous And Cultural Psychology: Understanding People In Context, ed. Uichol Kim, Kuo-Shu Yang., and Kwang-Kuo Hwang (New York: Springer, 2006), 247-262. Peng and his colleagues also provide a good explanation of Chinese Taoist thought in the chapter.

5 Technically, during the 5th and 4th centuries BCE in the area of what is today called Greece, there was no nation-state or country called Greece. The area was a collection of citystates, each self-governed, often referred to as Hellenes after the 4th century. This is called the Hellenistic period. For simplicity's sake, I refer to such city-states as "Greece." Most of the ideas and art that I discuss are from the Hellenic city-state of Athens. To read a good history of ancient Athenian rhetoric, see chapters 1-5 of George Kennedy, A New History of Classical Rhetoric (Princeton: Princeton University Press, 1994); or see Richard A. Katula, "The Origins of Rhetoric: Literacy and Democracy in Ancient Greece," in A Synoptic History of Classical Rhetoric, 3rd ed., eds. James J. Murphy, Richard A. Katula, with Forbes I. Hill (Mahwah, NJ: Routledge, 2003), 3-19.

6 I should note that even the distinction of "West" and "East" as a cultural or spatial concept or reference is Western European, as it tends to assume a White, Western, European global center. Re-center the globe on the continent of North America, and Europe is now the East, while Asia is the West.

7 Besides ancient Greek (Hellenic) philosophy and thinking that gained dominance in the medieval era of Europe when monks and priests copied and harmonized their texts with Christian doctrine, one can look to the Enlightenment for ways that Western dialectic became dominant in language and thinking, most notably in science and philosophy. While each are 
Many cite Aristotle's use of dialectic as one origin of Western European traditions of logic. He inherited his ideas from his teacher, Plato, who got his ideas from his teacher, Socrates. ${ }^{8}$ Socratic dialogue, as illustrated in Plato's dialogues, is a linear argument that consists of a question followed by an answer that leads to another question and another answer. It's a back and forth that is often adversarial. The answerer isn't usually on the side of the question-asker, Socrates. And the dialogue ultimately leads to the Truth, Episteme. For the ancient Greeks, to argue meant you engaged in conflict, comparison, and resolution.

This same dialectic logic can be seen all over ancient Greek culture. ${ }^{9}$ The Olympic games are one example, with lots of individual contests and few team activities. The way the city center, or agora, operated is another. The agora was where most civic and economic exchanges occurred, where one argued and haggled as a matter of course. Agon or conflict was how life was transacted in ancient Greece.

Thus, one's life and success in the civic or economic spheres were centered on conflict. If you were lucky or good enough, the conflict ended with your success and triumph over others. Conflict also defined the realm of home and family, or oikos. Many scholars of antiquity consider Homer's epic poem, The Odyssey, to be a kind of encyclopedia of ancient Greek culture. The telling of the poem was how knowledge and practices were passed down from one generation to another. It exemplified the culture and its ideas through a series of individual conquests and triumphs over a variety of obstacles and creatures, all so that Ulysses, the hero, could make it safely home to wife and hearth, yang returning to its yin. ${ }^{10}$ But for the ancient Greeks, getting home, being safe and in one's place, was dependent on previous conflict and winning. The epic poem's central lesson could be: Life is a series of contests that prove oneself and one's virtue, or arête.

The material conditions that made ancient Greek life afforded a particular set of relations to words, or logoi, that we inherit today in dominant English

quite different, thinkers like Kant, Bacon, Descartes, Hume, Locke, Adam Smith, and many others worked from linear and binary dialectic habits of language that created hierarchies and categories of phenomena and ideas.

8 To read more about dialectic, see Aristotle, Rhetoric, trans. W. Rhys Roberts (New York: Modern Library, 1954); Aristotle, Topics, trans. W. A. Pickard-Cambridge (Internet Classics Archive, 2009), http://classics.mit.edu/Aristotle/topics.html; and for discussion of Aristotle's works, see chapter 4 of James A. Herrick, The History and Theory of Rhetoric: An Introduction, 5th ed. (London: Routledge, 2016).

9 Richard Nisbett, a cultural psychologist, discusses the themes of "personal freedom, individuality, and objective thought" in ancient Greek culture in The Geography of Thought: How Asians and Westerners Think Differently ... And Why (New York: Simon and Schuster, 2004), 30. 10 To read about epic poetry as an encyclopedia of ancient Greek culture, see chapter 4 of Eric A. Havelock, Preface to Plato (Cambridge, MA: Belknap Press, 1963). 
language practices because of their Western roots. The term logos actually means "word," "idea," and "reason" itself. Since ancient Greece was primarily an oral society, logos was mostly spoken, breathed between people in exchanges. It makes sense, then, that the term used for words would also be the one used for ideas and reason in these conditions. The way one might experience an argument would be from the mouth of another person in front of them, coming from inside them, perhaps understood as a part of their essence, their virtue. Logos was a part of a person. It's easy to see how a person's ideas spoken, coming out of their body, might seem essential to that person, an inherent part of them. And in these conditions, words, ideas, like people are distinct from one another.

It also isn't hard to see how a back and forth, or "dialectic," is at the heart of most language practices. Our ideas about dialectic make up much of our orientations to the world and language. But how might dialectic in our world share in both the natures of conflict and consubstantiality, logos and Taoism? As you may be able to hear in my cursory description of Chinese Taoist and ancient Greek dialectic, they are quite different orientations to languaging and the world.

Of course, no orientation is unified, and there are lots of differences and nuances expressed through the ages; even the idea of a Western vs Eastern dialectic orientation is artificial. But my point in this chapter is to reveal the broader outlines of each orientation that are often embodied in habits of language that create us, so I'll speak mostly in generalities, knowing that while they break down eventually, they are still helpful. In the process, I want to argue tacitly that Taoist and Western dialectics are a part of my literacy story.

\section{TAOIST DIALECTIC LANGUAGING}

Almost every semester in the writing courses I teach, which can range from firstyear writing to graduate courses on rhetorical theory, I get a few students who are brave enough to ask me about my writing assignments. Their confusion is not in how I'm asking them to engage in the writing but in what I'm expecting from them as a product of that labor. They are used to teachers assigning categories of writing. This week, we are writing an essay that explores . . Next week, we are writing a research paper on ... The following week we are writing a journal entry on ... These categories of writing, or genres, are assumed to have essential or inherent features in them that a student will practice doing when they write them. These features make the genres known to everyone. I do not make this assumption. I don't think in terms of essential or distinct categories of writing assignments. This isn't how I understand languaging.

Part of my students' confusion comes from how I assign things. I pay careful attention to the process of labor I want them to engage in. The instructions are 
written as step-by-step processes. They are more minimal in describing what that labor produces, since I don't know what it will produce exactly for every student. I don't find it particularly fair to assume that all students in my courses will want or be able to produce the same kind of writing, the same kind of draft, for instance. I don't know if I'd want to read the same kind of draft from every student.

I also don't think it is necessary to fit every differently shaped student literacy into the same square hole of the assignment. Instead, I want to open up the act of writing so that it simply becomes labor. I give them simple expectations that provide estimated time spent on each step in the process (in minutes) and the number of words written or read (depending on what they are doing). I'll also give them key things I want them to engage in, like questions to address or ideas to wrestle with as they write.

Recently a student asked me in class, "What's a 'narrative inquiry?' I looked it up on the Internet but couldn't find any description or example of one." I called our assignment a "narrative inquiry" because the central goal was to inquire about or investigate some narrative in popular culture. Now, my labor instructions were clear about what and how I wanted them to do the work, but because some of my students had expectations about genres in such a course, they were trying to nail down the assignment as a category of writing. They were looking for the kind of document, the category, to draft that they thought I was telling them to write; meanwhile I was more interested in how they labored toward whatever draft they produced. Their orientation to school work was not to think in terms of labor instructions but to think primarily in terms of the category of product expected of them. And so I often ask some version of, "what happens in our class when the expectations for our languaging are not about a product to submit but labors to do?"

In my instructions, I give loose guidelines for the product that the labor will produce, such as "a document of about 3,500 words that focuses on one question you have about a narrative found in popular culture that you find interesting. Your central question should investigate how this narrative is made, understood, or created in a U.S. context." Now, this is just the description. The majority of my instructions offer a step-by-step process to engage in.

My larger purpose in such writing labor is to have a dialogue with each student through my responses to their work about what they've created and how it exercises the goals and competencies we are shooting for. Both writer (student) and readers (teacher and peers) are vital in assessing whatever they produce because we must dialogue, have a give and take. The assessment they receive on their writing is going to be a dialogue. It's gonna require both of us, and their colleagues' responses too. We can only make sense of the writer's work when we understand how it is read by others and ourselves in this classroom context. 
This approach to writing assignments I consider a Taoist dialectical approach to languaging and learning. I resist a number of assumptions about writing assignments and how they are assessed that are conventional in most classrooms, which are informed by Western dialectic traditions. I resist an essential and knowable (nameable) list of distinct categories of assignments, making the yin and yang of each laboring process that leads to a product possible. I resist a focus on products that are categorized as learning, which often ignores the processes, the laboring and diverse learning that emerges in classrooms organically. I resist the practice of the teacher evaluating alone, then dialoguing with the student after judgements are made, since I find the student and I must assess together from our own positions and habits of language. We must inter-judge. This last resistance of mine also rejects a strictly hierarchical arrangement in the judgement of language. Both yin and yang are needed in evaluating language. Why hobble ourselves, hopping on one leg of our dialectic, in the most important part of a class, assessment and feedback?

I find myself flying across the country often these days, giving lectures and workshops on antiracist writing assessment, talking about White language supremacy in schools and disciplines. When I'm on an airplane and I strike up a conversation with the person next to me, inevitably I'm asked, "So what do you do?" I don't like to say what I do precisely. In fact, I try to avoid this conversation. I know people will change when I tell them what I do, and in my view, not usually for the better.

But if I'm pressed I'll say something like, "I'm a professor and associate dean. I do research on writing assessment and racism." Often I get surprised looks after "professor and associate dean." I don't look like a professor, let alone a dean. I've been mistaken for an athletic coach, even an athlete, but never a professor. I know why. I'm a brown guy who looks considerably younger than he is, mostly because of the standards of youth and age that circulate in our culture. I'm only 5'7" but athletically built, having worked out in gyms for the last thirty years.

When you are steeped in a culture that uses Western dialectic orientations to language, it's easy to make these kinds of categorical judgements about people without seeing the flaws in such categorical logics. Many would call them harmless mistakes, others, unfair assumptions and prejudices. Maybe they are harmless, maybe not. How harmless are they if they are ubiquitous, happening all the time everywhere? How harmless are they if they affect other judgements and decisions that circulate around them, many of which matter more, like who gets a job or who seems dangerous in a routine traffic stop by a police officer?

These are not just categorical assumptions we make but ones that have inherent hierarchies of value attached to them. Who seems more trustworthy on 
a plane, the mysterious, short, brown, muscular guy with black hair next to you-is he Mexican, Cuban, maybe Puerto Rican?-or the taller, White guy with thinning sandy brown hair on the other side of the aisle-is he a banker or businessman? The associations that are tacitly linked to each of these categorical bodies are different and have consequences beyond innocent mistakes on a plane. What my Taoist dialectical orientation helps me see in these occurrences is that they are a product of language and logic systems that afford us these mistakes in judgement. It's not our assumptions that are the problem. It's our unchecked logic that creates such judgement problems.

In school, I never really understood the five paragraph theme. I mean, I knew we were asked to write it, but I had a hard time doing that. Its linear structure didn't feel right to me. It was hard to fit the discussion in my head into that linear structure, even when I was trying really hard to do it. Why? Well, things just didn't fit into topics or points so neatly for me. Discussing one idea always seemed like five or six things at once. The claim I might start with was not necessarily my thesis or central idea, but I wanted to start with it because it made sense to be in a different spot on a journey than where I would end up. And sometimes, it felt—and still does feel—more right to just cut to a new topic, a new scene. No transitions. They just slow things down, keep the reader from the joy of figuring out the connections.

I also feel that my readers need to know more, need to know about the things on the borders and edges of a topic, in order to know something as I do. I hope this means that they also need to do work. You cannot have meaning just handed to you. Reading and communicating are hard labors for everyone, readers and writers.

Say I was writing a paper in school about time and clocks. I might start thinking about the way we have a twenty-four-hour day, how clocks represent this in twelve-hour halves, and how this system comes from Egyptians' methods for counting daylight and night. This would lead me to consider the Babylonians' numbering system, which was sexagesimal, or based on units of 60. I'd realize quickly that I don't need that word, "sexagesimal," but I like saying it, so I keep it. It's a gift to my readers. This system is similar to Sumero-Akkadian systems that were based on sixes. Do the Babylonians or Sumerians have something to do with our idea of time and clocks? Did the Babylonians and Sumerians talk to each other? They lived near each other, right? Was there commerce among any of these ancient civilizations? If so, could that affect these systems, which are representational, like the alphabet and hieroglyphics? And what about $\mathrm{H}$. G. Wells' famous novella, The Time Machine, published in 1895? It compares 
different civilizations. That story explores time travel. Morlocks and Eloi. Hierarchical societies in time. Bad people of the dark and caves. Good people of light and the surface. But are these their essences or just categorical appearances? Do Morlocks and Eloi sound racialized? Is that racializing a function of time, day and night, light and dark, Eloi and Morlock? Cultural anxieties? Racialized projections? Do the symbols in front of us that create time also create race?

And a clock itself is just a symbol made up of other symbols. This would then make me think of the way divisions of six numbers are all over the place todaythey are symbolic to us in a number of ways. Units of twelve, a dozen eggs, twelve inches makes a foot. This could lead me to think about the influence that ancient Egyptians (and Babylonians) had on what we buy today in stores, like a dozen eggs, or what seems complete. There are many religious traditions and myths that identify twelve as a sacred and complete number. Can you imagine buying just one egg, or three, or seven in a store? If there were just piles of eggs in bins at the supermarket, how many would you take at a time? Why? There seems to be a connection, a logic or link that connects our sense of time to Sumero-Akkadian counting systems and how many eggs we buy at any time, which is about what symbolizes wholeness or completeness. Twelve hours in a day. Twelve eggs in a dozen. Twelve Hebrew tribes. Morlocks and Eloi. Yin and yang. Time and the spaces it makes. Race and the divisions it makes. Symbols and the meanings they make. Division and the conflict it makes. Wholeness and the unity of opposites.

This kind of non-linear, even associative, logic did not pay off well in school for me. But it felt natural. It makes sense. It's fun. Perhaps my own languaging came about because of the dialectic I had grown in my home with my twin brother, grown through our twin ways of languaging together.

\section{WESTERN CATEGORIZING AND ESSENTIALIZING}

What made my literacy road rockier was that I enjoyed, even reveled in, paradox and contradictions, at least in thinking and writing, even for school purposes. The point of the Western dialectic is not to embrace opposing arguments, not to provide ambiguity and paradox, not to consider how those other voices might be reasonable or probable. The goal in Western dialectic, when translated to written argumentation in classrooms today, has been to offer an unambiguous answer and defend that answer, to present a strong and unified position which allows the writer to win the argument.

But I've never really been that interested in winning arguments. I have always been more interested in playing with language, playing with people together, and participating in verbal exchanges. Competing and conflict ain't comfortable for me. 
But in classroom writing, the point usually wasn't to hold opposing ideas next to each other, to juxtapose them and let them be, although that can happen. The point was to compare and evaluate, then decide which is stronger. The point was never NOT to win the argument. But I wonder: Why must we have winners and losers at all in such language games? Why must the goal in any persuasive moment be to win the discussion or argument? Why can't the goal be to explain and understand your ideas next to others? Why can't our goal be to dialogue, or protect and encourage, even aid the one with whom you are engaged?

Western notions of logic that are encased in standards of English writing in schools tend to ask students to counter or synthesize opposing ideas into a singular, unambiguous conclusion. This is the definition of clarity, order, control, and logical organization in most standards of written English, and it comes straight out of Aristotle. It's one of the most common habits of White language (HOWL) in English. And it works with an assumption that there is usually one best view, one winner. It says that focusing mostly on one position is a stronger, clearer way to understand things. What I'm describing are two habits of HOWL, a universalized and naturalized orientation to the world (habit one) that is combined with categorizing and essentializing. The categorizing is understood as clarity, order, and control in language practices (habit two).

Growing up with a twin brother by my side who was always ready to discuss and test ideas with me made me perhaps more willing to sit with ambiguity and see questions less like linear problems to solve than as a give and take, a back and forth, a dialogue. Compromising with him or understanding my brother was always more fulfilling than winning or chancing a loss. I often say I think in webs of ideas, but maybe it's just that I don't usually think linearly. I don't think in terms of wins and losses, of hierarchies, of steps or things like that. I can, of course, and I'm often asked to think in linear terms, but it has not been my first inclination. But even after I'd figured this out, I still couldn't shake the Taoist-like orientation in school.

In my senior year's advanced writing class, I had to write a paper about some issue or question I was interested in understanding better. I was in a new school, having just moved to Corvallis, Oregon, and living with my nana, who would die of cancer less than a year later. I wrote a paper about how science and the arts might not need to be in contradiction to conservative Christian values and beliefs encapsulated in the Bible. I essentially was arguing that maybe I could be both a Christian who believed in the infallible word of God in the Bible, believed that my nana had a soul and was going to heaven, as well as someone who accepted scientific explanations of the world like evolution and carbon dating that showed the planet to be much older than many in my church and family seemed to believe. 
I asked: Why can't I accept the idea that we don't have any proof of something called the soul, that there is no way to know for sure? Why can't I believe that there is no good reason for my nana's chronic, debilitating pain from cancer and chemotherapy, that her life makes no sense, hurts all of us, and depreciates the image of God? Why can't I hold equally to the belief of a loving God who would not hurt his flock, who has some kind of plan that we don't know? And yet, by having no evidence of such a master plan, it is right to question the existence of such a plan, to question the grounds of my own faith and that of my nana's, even as I hold tightly to that faith because it was all I had at that time to give me comfort? Why can't faith not be enough and simultaneously more than we need?

I showed this paper to my uncle Bill, whom I admired. He was a microbiologist, a professor and scientist at Oregon State University, and a respected member of our church, the Church of Christ. He baptized me earlier that same year. I figured he would have a foot in each world as I thought he did. I wanted his feedback before I turned in the paper. I wanted that paper to be good, and I wanted the conversation with him because he was the only man in my life. The question was important to me, as was my nana.

We sat on his bed in his two-story house on Roosevelt Drive in Corvallis, and he told me that I couldn't have it both ways, that if I believed in God and the Bible, then I couldn't believe this other stuff. He was expressing his Aristotelian and Western orientation to the world that he wanted me to accept, but I struggled with the categories, the essentializing, the this-or-that-ness of his response. I struggled with his HOWLing at me. I wanted things to be this-and-that. He called me agnostic, said I should be careful. I'm dancing with blasphemy, or worse, apostasy.

I thought it ironic that he would be so closed off given that he was a scientist himself-wasn't his own research a paradox in this question about God's plan and everlasting souls? The experience made me deeply sad and unsettled inside. I was disappointed that I wasn't encouraged the way I envisioned his words to me would be. I thought my words were good. I thought he would be understanding or at least provide a way to inquire with me about the questions I was asking. I didn't really want his answers. I wanted to have the questions. But to him, he was saving my soul, saving me from a Godless life, or a life of equivocation. $\mathrm{He}$ was demonstrating his Christian love for me. This paper, to him, led to hellfire and damnation. There was only belief and faith or nonbelief and equivocation. These were distinct opposites in his life. They shared no borders.

I thought he'd say that this paper really opened his eyes, that I was smart, that I could be someone like him. But I couldn't be someone like him, a White scientist from the Midwest, a mostly yang. I wanted both yin and yang. I wanted both the sciences and the arts, and I wanted my faith. It turns out ultimately I couldn't have the latter, the faith, at least not like his. I didn't lose it, as the 
popular saying goes. I never actually possessed it, but I know exactly where it is, where people keep it, and how they nurture it and often overfeed it. But in my youth, I just wanted faith like his. It seemed like the right thing to believe because everyone around me seemed to believe in it. It was comforting in the way a child believes his dad or mom can do anything, knows everything, so they don't see the weaknesses, the contradictions, the paradoxes. It's fast thinking.

Maybe what saved me at this moment when I could have taken a dive into a darker place was the considerably warmer response my teacher gave me. His name was Mr. Baldwin, a kind, soft spoken, platinum blond haired White man of about forty or so with a dry mouth. I could hear his tongue smack dryly in between his words. I remember very little of that class except this paper and one comment he wrote on it.

Beyond the many scribbles and circles scratched on my draft that noted the errors, he wrote at the top of the first page: "Most students your age don't think this deeply about such topics." That comment sustained me into my senior year of college, when another middle aged White male English professor would affirm me as a writer. I like to think that Mr. Baldwin looked past most of my non-Western orientation to language and saw the thinking on its own terms. But I don't know. What I know is his comment and how I read it as affirming, next to the errors and the "B-" grade.

\section{PLAYING D\&D AS LOGOS-CONFLICT}

Because we were twins, my brother and I shared everything. We were always by each other's side. My brother and I played lots of games together. In part, we did so because we were latchkey kids. My mom could not afford babysitters, so when she was at work and we were not at school, we were behind a locked door in our apartment or trailer. The games we gravitated to eventually were not board games. Our games were language and dialectic games.

I had one problem though. I hate conflict and competition. It's a disposition I still carry today. All through childhood, I tried very hard to avoid conflict and situations that required a winner and loser. I disliked most board games because of this. Monopoly, Risk, chess, checkers, Stratego, you name the board game, and I likely couldn't handle playing it. I just felt awful and uncomfortable while playing. I didn't mind losing, but I really disliked seeing others lose. The competition was like razor blades on my feet.

I felt uncomfortable for those around me when someone publicly lost at a game or was losing. Sure, I wanted to win, but I didn't want to win by having others loose. Perhaps a part of this disposition against direct conflict was the fact that much of the time, I was playing with my twin brother, and I really didn't like to see 
him lose. It felt like I was losing, and in a way I was. In Buddhist terms, winning and losing inter-are. They share in each other's essence. They require each other.

When I think about winning that second grade reading contest, I realize that most of my experience of it was not of competing against my colleagues in school, even though technically I was. Most days, there was no face-off with my competitors. The play of the game itself was reading after school. It was a daily practice of opening books and fingering lines of text, speaking words, of pushing myself to read more, to do something I was just finding out that I loved. So I don't consider that contest a competition in the same way that I grew to feel chess or Monopoly was. It was a daily practice more than a competition to win. I really just wanted to read. I don't have those trophies anymore, but I still have my reading practices, my words, the daily practice of conjuring words.

I realize that I was also younger then, just figuring out who I was, and it isn't like the reading contest was not uncomfortable at times. On Mondays, the teacher would color in the bar graphs on the back wall of the classroom. Each bar had a student's name next to it. The wall showed our relative progress at reading books. It compared each student's progress next to their peers. How many books did each student read? The graphs were meant to help us set goals, but what I felt was this burgeoning sense of dislike for competition through quantified comparisons that made hierarchies, that is, a winner and levels of losers.

So when Dungeons and Dragons (D\&D) came along, I jumped at it. I was fanatical about the game. My brother and I played that game just about every day from the sixth grade until we graduated from high school, then into college. If we weren't playing it, we were thinking about it, reading up on it, creating adventures and characters. We still play today.

In $\mathrm{D} \& \mathrm{D}$, there is no winning, not in the traditional, board game sense. There is just never-ending play. A game or campaign never has to end. There's always another quest, another problem to solve, another land to explore. There is conflict, but that conflict is with creatures and people that are not real. They are make-believe, just words with relations to people who only exist in our minds. Playing was living and breathing a fantasy. Playing D\&D did not feel like a conflict where someone in the room had to win and another lose. We were not pitted against each other. One of us was the Dungeon Master (DM) creating the adventure for the player, and the other was the player, the one who went on the adventure.

Playing, then, was a collaboration. It felt like acting and telling a story all at once, which is why it is called a "role playing game." Each session was a story in which neither of us knew what the next stage or step was going to be because that was determined by both of us together in concert and organically. For instance, Tad created a situation as the DM, and I as the player reacted to it in whatever ways I saw fit within the confines of my character, the context, and 
my present purposes, then he reacted, then I did. And the story continued in unexpected ways.

The characters and contexts continually changed. Most adventures were journeys, quests, and long strings of actions and reactions. The point of the game - and the fun of it — was the process, the journey, not an endpoint, not competition, not some signal that someone "won" at some point. D\&D is a game that resists conventional winning and losing. It even resists thinking of the game as achieving a single goal or outcome, like scoring the most points, winning against other players. Instead, for us, it was about the ever-unfolding story we told and acted out together. And since everyone loves stories, everyone wins, especially since everyone has a hand in making the story.

The game should have been called Dialectic and Dragons. To play means a back and forth between the DM and players, players and NPCs (or nonplayer characters that the DM controls). D\&D is a game made entirely of language. While it is only ostensibly about fighting and conflict, really it is about wording, creating, and collaboratively telling a story that always has a next chapter. And so, it is also about an endless cycle of ups and downs, of new contexts, and change, of endless creating with words.

This game nurtured my language dispositions, but more importantly, it offered a way for me to do Freireian critical practice as play. We were creating worlds and characters that required us not just to understand or invent such things but to question them, create opposing ideas, characters, motivations, and worldviews - and all through words written and spoken, all through interactions that required a yin and yang, a this-and-that-ness of play.

In a way, to engage seriously in the play of $D \& D$, as we did, we had to engage in Freirian critical reading, pose questions about paradoxical word-worlds and word-characters. And the game was better when all sides were compelling, when choices and decisions were difficult to make because it was not a question of right or wrong, good or evil, but a question that presented one paradox after another. It was two boys of color storying themselves into existence.

I'm reminded of one refrain in Thomas King's autobiographical book on stories, a refrain that he repeats in each chapter: "The truth about stories is that that's all we are." ${ }^{11}$

"Okay, what are you gonna do?" Tad asks me. We're sitting cross-legged on the floor in our bedroom in the trailer, Dungeons and Dragons books arranged neatly around us, the Dungeon Master's Guide, Player's Handbook, Monster Man- 
ual, Deities and Demigods, the good one, the first edition with Cthulhu and Melnibonean Mythoi in it.

My brother has a DM's screen up to hide his notes and maps. It's late on a Friday night, our prime time for playing D\&D. We've been playing for hours already. There's a pad of graph paper between us. We're using it to sketch out complicated arrangements: who is where, what rooms look like, etc.

"How many orcs jumped out in front of me? Where are they exactly?" I ask, scanning my character sheet, which has my magic user's stats, abilities, equipment, and spells written on it. His name is Schmindrake. He is my favorite character and will continue to be as I grow older, enter high school, college, and later. In fact, I'll end up keeping this character sheet, recopy it a few times, for another thirty-five years in real life, and slowly let the character retire.

Schmindrake the character will eventually become an Arch-Mage, a very high level magic user, and he will define me as a D\&D player. I'll get to know him, flesh out his personality, use him as an archetype for other characters, a test case for ideas. He will come to voice many different things in my life, frustrations, joys, pains.

I'll think of him as my alter-ego of sorts, the mage who could do just about anything. The words that make him make me in the process, words I have made. And so, I have been Schmindrake, yet he isn't real. Through him, I will save cities, conquer empires, and build my own floating castle in the clouds. I will travel to different planes of existence. I'll go to Hell, the Astral and Ethereal planes, searching, usually finding. Schmindrake will save me as a boy from the cruelty of neighbors and teachers, from the racism around me. In critical moments when I needed an escape, Schmindrake's magic was real to me. He took me away to other lands where I was the hero.

I see now that being a professor in real life is very much like being an archmage in D\&D. Both have their books and incantations, their spells and words that do things in the world. Both are magic users. Both must study. Both conjure things, one with the arcana of fantasy, the other with words, theories, and ideas. It's clear I have always been on the mage-professor path, even as a boy.

Sitting on the floor in our room, I have the Player's Handbook open to the page where the second level spell, "Web," is described. My character recently acquired the spell, and I'm excited to use it.

"There are just two orcs. Here's what it looks like." My brother draws the dungeon hallway on the graph paper. He draws the alcove where the orcs originally jumped me and puts little "O"s where they are and an "M" where my character is. "They are about ten feet apart, here and here." He points at the "Os." "And you are here, about ten feet from them." We had just rolled initiative, and I had the higher roll, so I get to go first. 
"I'm going to cast my web spell at their legs and feet, anchoring the web to the floor right there and there. My range is two, so I can reach them."

"Saving throw?" he asks, his eyes stay looking down at his notes.

"Negate or half strength, depending on circumstances."

"They have room to jump out of the way, so if they make their saving throws, it would negate the web. Is that what you want to do?” Tad asks.

"Yes, I want to question them. I know Orcish." I make a web shooting sound and a motion with my hands, like I'm casting a spell. My brother rolls the twenty sided die twice. He makes a note on his paper, looks back at a page in the Monster Manual.

"Okay, you speak your incantation, and as you do this, you can see the orcs get nervous. You know they don't like magic. They seem scared now."

"You are mine, bitches!" I say, as my brother talks.

"The spell is verbal, material, and symbolic, so your web springs forth from your hands in a shimmering silver light as you speak. It comes through your hand gestures and sticks to one of the orc's feet, catching him in the gooey threads. He's stuck. He can't do anything."

"What about the other one?"

"The other one jumps free. He's now here." Tad erases one of the "O"s on the graph paper and puts it in a new spot near the middle of the dungeon hallway twenty feet from the webbed orc and in front of my character.

"Is it my turn still?"

"Yes, the orc used his action to jump out of the way. He had to re-adjust himself, but he will get to attack this round after you." Tad takes a sip of his iced tea. "What are you gonna do? You can see he's about to make a run for it."

"You mean like retreat?"

"Yes, he looks scared of your magic." Tad makes a scared face, imitating the orc's reaction.

“'You cannot escape, orc!' I'll say to him, and I'll hit him with my magic missile." I point on the graph paper at the free orc in the hallway. "I only need one of em to get the info." I make a laser sound. Magic Missile is my favorite spell. It doesn't miss. There's no saving throw. The only downside is that it doesn't do a lot of damage, but I don't need a lot in this case.

"You sure you want to do that? He looks scared, like if you did nothing, he'd run. Also, you may need that spell later." My brother is reminding me slyly that I have options, that it's not necessary to kill everything. I pause in my excitement at killing the evil orcs who just tried to ambush me. It's an ethical paradox for a fourteen-year-old boy. Do you kill the orc who is about to retreat, or do you let him run and live his life, perhaps to do more bad things or change his ways? 
"These mother fuckers just ambushed me! They were gonna kill me. They were likely part of the orc clan that slaughtered the villagers. Don't I have to kill him? I mean, they did hire me to take care of this problem."

"But what does 'taking care of this problem' mean? Kill everyone?"

"Scorched Earth, man!" I yell. We both chuckle.

"Remember, you don't know if these orcs are the same orcs that attacked the village. For all you know, these orcs are just protecting their underground lair. This is an abandoned temple. Besides, Lord Vain never said you had to kill them all, just that he wanted to be free of the orc problem. Orcs are not that smart, nor brave. The villagers are mostly lawful good."

"Hmm. Right. What do I really know here? I'd probably do the same thing if I were these guys. I am good, but I'm chaotic good, so I don't have to always abide by the laws."

"You are more about good with personal freedom."

"Whatever gets the job done. Ends over means, man."

"Yes, but what means really help you get to your ends here? Your end could be to scare them off, or to kill them all, or something else. Keep in mind, you are fifth level. If you shoot magic missiles at him, he's likely dead. Just saying. And of course, you'll only have one more magic missile spell today. Might need it later."

"Well, he could run off and tell his buddies that I'm coming, and that wouldn't accomplish the mission. There could be a hundred of them."

"Actually," Tad looks at the Monster Manual, fingers the page, "between 30 and 300."

"So a lot more than I can handle at once," I smile at my brother. He raises his eyebrows and gives a look like, who knows? "Do I know how many orcs the villagers saw? Did they tell me?"

"Roll your intelligence." I roll the twenty-sided die.

"Sixteen after my bonus."

"Okay, you recall that Lord Vain said there was a legion of them."

"Legion? How many is a fuckin' legion?"

"In the ancient Roman army, that shit was thousands." I look at him with a flat, close-lipped smile and a raised eyebrow as if to say, how the hell do you know that? My brother knows I'm wondering that. "I looked it up, dude. DMprep."

"So there's like thousands?"

"Not likely, given that you know they don't have clans much bigger than a few hundred. You think he meant that there were a lot of them, more than he could count."

"Okay, that settles it. While I hate to kill a dude running away, I'mma have to do that in this case. Ma job is to protect the village. This is the safest choice." 
"You can see the orc is already turning to run away. 'Aaaahhhh,' he's screaming in terror of the magic he just saw. If there is anyone around, they'll hear him screaming."

"I fire my magic missiles." I wave my hands in mock spell-casting and make more laser sounds. "Shut yo ass!" I say as if I'm speaking to the orc.

"They automatically hit. Roll damage." I roll a four-sided die twice.

"That's three, seven, plus two-nine points, baby!" I'm excited. I know orcs do not usually have that many hit points.

"He turns to run away screaming, 'aaaah, no, no!' The blue magic missiles tear into his flesh, one in his back, one right at the base of his spine and head. His orc flesh peels and burns away." Tad makes an explosion sound. "The orc cries out in pain. 'Aaarrgh!' You can see his eyes are wide with fright as he dies. The orc crumples to the floor, dead. His corpse is smoking. The other orc drops his rusty sword and cowers. You can see he's scared shitless. He's stuck in the web up to his waist."

"I turn to him and strike a wizard pose, like I'm gonna cast something at him."

"He whimpers. 'Oooh, please, please,' he says, 'don't kill with your powerful magic! You great wizard.' He's speaking Orcish. He bows his head.” I can tell Tad is trying to make the orc sympathetic, more interesting than what the Monster Manual describes him as. He may be an evil orc, but he ain't just that. Tad's roll playing the orc. I want to go along with it. It's more fun.

"I ask him in Orcish, "Where can I find your clansmen who attacked the villagers?" I wiggle my finger as if I'm going to cast another spell. "I will spare your life, orc, if you tell me the truth—and I'll know if you're lying," I say in an authoritative voice. Another finger wiggle.

"You can see that he pisses himself. 'But Wizard Lord,' he says, 'Spilge Bottom bound to orcish ways.' He pleads with you, 'Please do not kill poor Spilge Bottom. I have sworn my bones to clan of Flesh Eaters. For generations Lord Vain's family slaughter us. We fight back. We survive. This is our way,' the orc tells you." Tad is doing his best orc imitation.

"Well, does he seem like he is lying? Can I tell?"

"Roll your wisdom." I roll the twenty-sided die.

"Fourteen."

"You think, he's too scared to lie to you and too dumb."

"I say, 'Well, Spilge Bottom, you have chosen the wrong side; therefore, I have no choice.' I raise my staff in a menacing way, and see if this convinces him to tell me what I want." Tad thinks for a second or two.

"Okay, roll charisma." I roll a twenty-sided on the hard back of the Player's Handbook. The die makes the familiar sound, a thick crackle. 
"Eighteen with my bonus, good?"

"Spilge Bottom says, 'Ol' Spilgey tell you all. It not Spilgey fault. Spilgey forced to take bone-oath in clan. Spilgey just want to live."”

"Okaaay," I say, squinting my eye at him. Finger wiggle.

"Spilgey have new master, Master Wizard Lord. Please, please, Master, please, Ol' Spilgey realize me no match for Master Wizard Lord. Ol' Spilgey promise to do all Master ask. Spilgey tell you all.'” A chaotic good magic user taking on a lawful evil orc as a henchman, I think, it is odd, but those are our games, odd in their deviations from the rules, like real life, I think. Rules are artificial, just made on top of life. Besides, I feel I'm starting to like Ol' Spilgey. Maybe I can change him, help him. He'll bring spice to the campaign. The game is always better when I feel like we are breaking old rules and making new ones.

"Okay, Spilgey, you are gonna have to do what I say and change your ways. Got it? I'll take care of you."

"Oh yes, Master Wizard Lord, Ol' Spilgey change good, change every which way."

"Well, Spilgey, let's get to the bottom of things. Sounds like we got work to do."

\section{THE PARADOXICAL NATURE OF TWIN LANGUAGE}

My brother, Tadayoshi (or Tad), and I are identical twins. Growing up, most people could not tell us apart. Shortly after we were born, my mom had to return us to the hospital, have our feet dipped in ink and printed again, to find out who was who. She couldn't tell the difference. When we were toddlers, Tad and I had our own "twin language." That's what my mom called it. We spoke it to each other only. No one could understand it but us. It was fun to be a mystery to those around us. Perhaps we understood intuitively how powerful and magical words are. They create us. And so, you don't give them to just anyone. And many of us practice giving them to ourselves first.

Growing up, we talked the same, liked the same things, and were always together, usually playing D\&D. Even today, most of these things have not changed. We loved each other, always have, and yet wanted to be different from one another. I wanted to be my own person, to be recognized by others as such, yet also deeply appreciated my twinness and the fact that no one could tell us apart. We liked the same movies but sometimes for different reasons. We both loved the films Dragonslayer, Conan the Barbarian, and Excalibur. They were fantasy adventures like those we enacted in our D\&D language games. Tad liked the films for the dragon, Conan, and King Arthur. I liked Urlich, the wizard (played by Mako), and Merlin, all mages. 
Tad was always there for me, always supportive, always had my back, always. He has understood me. I can trust him with anything. To family and friends, we were "the boys," and Asao and Tad, the individuals. In fact, most of our lives, my brother and I have joked that the other is the "yin to his yang," meaning that we made each other whole when we needed to. Together we have been complete.

But being a twin also created material conditions that produced a natural unity of opposites for me. We were the same to others, yet different to ourselves. We were the same to ourselves, making each other whole, yet different in some likes and dislikes. My brother did not pick up reading nearly as quickly as I did, for instance. He also is not much of a planner, is much more impulsive, and listens to his intuition to make most decisions. I like to plan, then deviate from it, but I want the plan. I've never really considered my intuition in most decisions, big or small. I have leaned on my wife, Kelly, for that.

We know these differences, yet feel and see many other similarities. So we were independent and strong willed but also needed each other, wanted each other in our lives. Sometimes my brother took the lead in social situations, at other times I did. The context and people determined when we would adjust our roles, so we were both leaders and followers. We shared a bedroom and bed for most of our growing up, well into junior high school years, when we got bunk beds, a bed that is two beds yet one bed. Through these material conditions as a twin, I was primed to accept more freely ambiguity and paradox, primed to resist categories and the essential characteristics that often went with those categories. Perhaps many twins feel this way.

Of course, I didn't understand any of this growing up. I was not raised in a culturally Japanese household, and my family did not practice Taoism, Shintoism, or Buddhism. And yet, our material conditions encouraged an orientation to the world and language that agrees with East Asian dialectic. In my preteen years, I experimented with various religions: Catholic, Baptist, Lutheran, the Church of Latter Day Saints, among others. I read other faith's literatures, even read the Book of Mormon. I went to their churches. Nothing about this seemed odd to me. Mom was okay with my experimenting.

As we've grown older, my brother and I, unbeknownst to the other, acquired Buddhist practices in our work and lives. Tad even got a degree in religious studies, went to Wesley Theological Seminary as a grad student (not a seminarian). Today, my brother is a diet coach and nutritionist, and he conducts his business with a strikingly similar philosophy as I do my teaching. His focus is on enjoying the journey of the diet or context prep (for athletes), not an outcome like some ideal weight or trophy.

Believing and not believing. Being this and that religion. Looking back now, it all fits the orientation to ideas and language that I see in my story. I didn't 
see why I couldn't have all of those religions, or all the good parts as I saw them at the time, while acknowledging the bad parts too. Richard Nisbett, a distinguished professor at the University of Michigan, offers another important element of Taoist dialectic that coincides with this impulse of mine:

The Chinese dialectic instead uses contradiction to understand relations among objects or events, to transcend or integrate apparent oppositions, or even to embrace clashing but instructive viewpoints. In the Chinese intellectual tradition there is no necessary incompatibility between the belief that $\mathrm{A}$ is the case and the belief that not-A is the case. On the contrary, in the spirit of the Tao (道) or yin-yang principle, A can actually imply that not-A is also the case, or at any rate soon will be the case. (“物極必反”) Dialectical thought (Chinese version) is in some ways the opposite of logical thought. It seeks not to decontextualize but to see things in their appropriate contexts: Events do not occur in isolation from other events, but are always embedded in a meaningful whole in which the elements are constantly changing and rearranging themselves. To think about an object or event in isolation and apply abstract rules to it (as in Western intellectual tradition) is to invite extreme and mistaken conclusions. It is the Middle Way that is the goal of reasoning. ${ }^{12}$

Nisbett explains the way context and the embeddedness of ideas and words in the world help make meaning for Chinese Taoist dialectic orientations. Contradictory traits or essences are allowable, even inevitable, in the world. Chinese dialectic presumes that you cannot separate abstract ideas, like "cow," from the cow you know (or don't know) in real life, or the cow in the context by which you know cows, or will know them, or the way others know them. This is similar to Freire's ideas about posing problems in his critical reading practice. The questioning Freire asks of us helps us keep the ideas and words in front of us contextualized, embedded in our unique histories, in our own material conditions. It helps us experience and feel the this-and-that-ness of our words and world.

In my early years growing up, I struggled with language in school work, yet I was deft at it on the block and in D\&D sessions. I hated reading in school. It was the symbol of me as a remedial failure. At home with my brother, I loved reading and language, had a science fiction and fantasy book club membership. Language was the power I had. I was a mage, a spell caster.

Richard Nisbett, Geography, 27. 
I had a White mom, but no one saw me as White. I was Brown. It all made sense if you knew my life, knew the story of my mom and dad. I was Japanese, but everyone saw me as a Mexican. I was a contradiction, a paradox. I was a member of the Church of Christ, actually enjoyed the sermons on Sunday, the hymns. I enjoyed the language of church, yet I struggled to buy into the doctrine, the extreme conservatism, the gender hierarchy that relegated all women to subordinate roles. Meanwhile in my real life, women were the most important people, doing everything. They were the leaders.

I also found beauty and elegance in the idea of grace while I resisted church doctrine and practices. Today, I still have fond feelings when I hear the sad hopeful sounds of the hymn, "Amazing Grace." It is my nana's voice, her sentiment to me as she held me in her warmth and rocked me in her green chair, singing me into being. It was reassuring to a poor kid in the ghetto to listen to hope in a song. Life may be shitty here, but not for long. I'll be bright and clean and, yes, angelic and White.

I lived with these contradictions as the landscape on which I cultivated my dispositions toward language and my love of language. Unfortunately, doing so didn't solve all the problems in my life, especially not the racism. Racism was connected to my own embodied languaging. And I did not control much of it. How does a twelve year old come to terms with such things? How does he acquire the language needed to understand and thrive as a languageling in a White world filled with White words? 


\section{ABOVE THE WELL}

In Above The Well, Asao Inoue explores race, language and literacy education through a combination of scholarship, personal history, and even a bit of fiction. Inoue comes to terms with his own languaging practices in his upbring and schooling, while also arguing that there are racist aspects to English language standards promoted in schools and civic life. He discusses the ways students and everyone in society are judged by and through tacit racialized languaging, which he labels White language supremacy. Inoue's exploration ranges a wide array of topics: his experiences as a child playing Dungeons and Dragons with his twin brother; considerations of Taoist and Western dialectic logics; the economics of race and place; tacit language race wars waged in classrooms with style guides like Strunk and White's The Elements of Style; and the damaging Horatio Alger narratives for people of color.

Asao B. Inoue is Professor of Rhetoric and Composition in the College of Integrative Sciences and Arts at Arizona State University. Among his many articles and chapters on writing assessment, race, and racism, his article "Theorizing Failure in U.S. Writing Assessments" in Research in the Teaching of English won the 2014 CWPA Out-

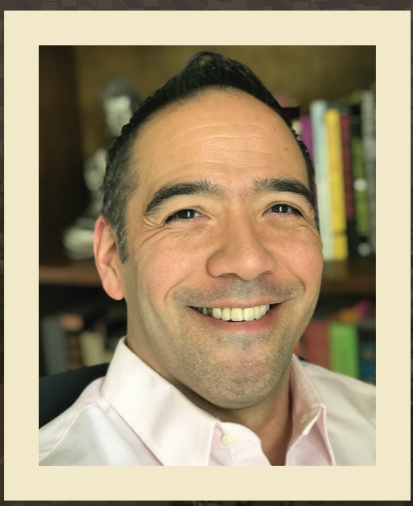
standing Scholarship Award. His co-edited collection, Race and Writing Assessment (2012) won the 2014 NCTE/CCCC Outstanding Book Award for an edited collection. And his book, Antiracist Writing Assessment Ecologies: Teaching and Assessing for a Socially Just Future (2015) won the 2017 NCTE/ CCCC Outstanding Book Award for a monograph and the 2015 CWPA Outstanding Book Award.

\section{Perspectives on Writing}

Series Editors, Rich Rice, Heather MacNeill Falconer, and J. Michael Rifenburg

The WAC Clearinghouse Fort Collins, Colorado 80523 wac.colostate.edu

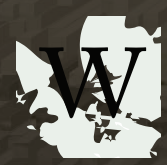

\section{Utah State University Press}

Logan, Utah 84322

upcolorado.com/utah-state-university-press 